\title{
Dengue fever and insecticide resistance in Aedes mosquitoes in Southeast Asia: a review
}

\author{
Soon Jian Gan', Yong Qi Leong 1,2, Muhammad Fakrul Hakim bin Barhanuddin', Siew Tung Wong1, \\ Shew Fung Wong ${ }^{1,3^{*}}$, Joon Wah Mak ${ }^{1,3}$ and Rohani Binti Ahmad ${ }^{4}$
}

\begin{abstract}
Dengue fever is the most important mosquito-borne viral disease in Southeast Asia. Insecticides remain the most effective vector control approach for Aedes mosquitoes. Four main classes of insecticides are widely used for mosquito control: organochlorines, organophosphates, pyrethroids and carbamates. Here, we review the distribution of dengue fever from 2000 to 2020 and its associated mortality in Southeast Asian countries, and we gather evidence on the trend of insecticide resistance and its distribution in these countries since 2000, summarising the mechanisms involved. The prevalence of resistance to these insecticides is increasing in Southeast Asia, and the mechanisms of resistance are reported to be associated with target site mutations, metabolic detoxification, reduced penetration of insecticides via the mosquito cuticle and behavioural changes of mosquitoes. Continuous monitoring of the status of resistance and searching for alternative control measures will be critical for minimising any unpredicted outbreaks and improving public health. This review also provides improved insights into the specific use of insecticides for effective control of mosquitoes in these dengue endemic countries.
\end{abstract}

Keywords: Dengue, Aedes mosquitoes, Prevalence, Insecticide resistance, Southeast Asia

\section{Background}

Aedes mosquitoes (Diptera, Culicidae) are the main vectors for several diseases associated with arboviruses, such as dengue, dengue haemorrhagic fever, dengue shock syndrome, yellow fever, chikungunya and Zika virus infection. There are two medically important species of Aedes mosquitoes that are associated with the transmission of dengue virus: Aedes aegypti (Linnaeus, 1762) and Aedes albopictus (Skuse, 1984). The adults of Ae. aegypti and Ae. albopictus are both black in colour but they can easily be differentiated by the pattern of white scales on their dorsal side of the thorax: Ae aegypti has two straight lines surrounded by curved lyre-shaped lines on the side while Ae. albopictus has a single broad line of white scales at the middle of the thorax [1]. The adult female Aedes

\footnotetext{
*Correspondence: shewfung_wong@imu.edu.my

${ }^{1}$ International Medical University, 57000 Kuala Lumpur, Malaysia

Full list of author information is available at the end of the article
}

mates, takes blood meals, lays 60-100 eggs in artificial and natural containers and can survive an average of 20-30 days. Aedes mosquitoes are considered to be daytime biters as they bite during dawn after sunrise and at dusk before sunset. Upon ingestion of dengue virus from an infected person, the virus will multiply in the salivary gland of the mosquito for $8-10$ days (incubation period) prior to transmission to another person during subsequent blood meals. The flight range of Aedes mosquitoes is relatively short, in the range of 50 to $200 \mathrm{~m}$ from their breeding sites [1].

Aedes aegypti originated from Africa as a zoophilic tree-hole breeder (Ae. aegypti formosus) [2] and is domesticated or stays in close proximity to humans throughout the tropical and subtropical regions outside of Africa. This human-adapted species is hypothesised to have spread to the New World and Asia via increased global trade. Aedes albopictus (Skuse, 1894) is originally from Bengal, India and is indigenous to 
Southeast Asia [3]. It has spread to Africa, the Middle East, Europe, North and South Americas and Pacific Islands. To date, both Ae. aegypti and Ae. albopictus are widely distributed throughout the world, including Southeast Asia [4, 5] (Fig. 1).
Four antigenically distinct serotypes of dengue viruses (DENV-1, DENV-2, DENV-3 and DENV-4) can be transmitted to humans during the bite by an infected female Aedes mosquito (also known as horizontal transmission). Following the blood meal, the virus attaches to various

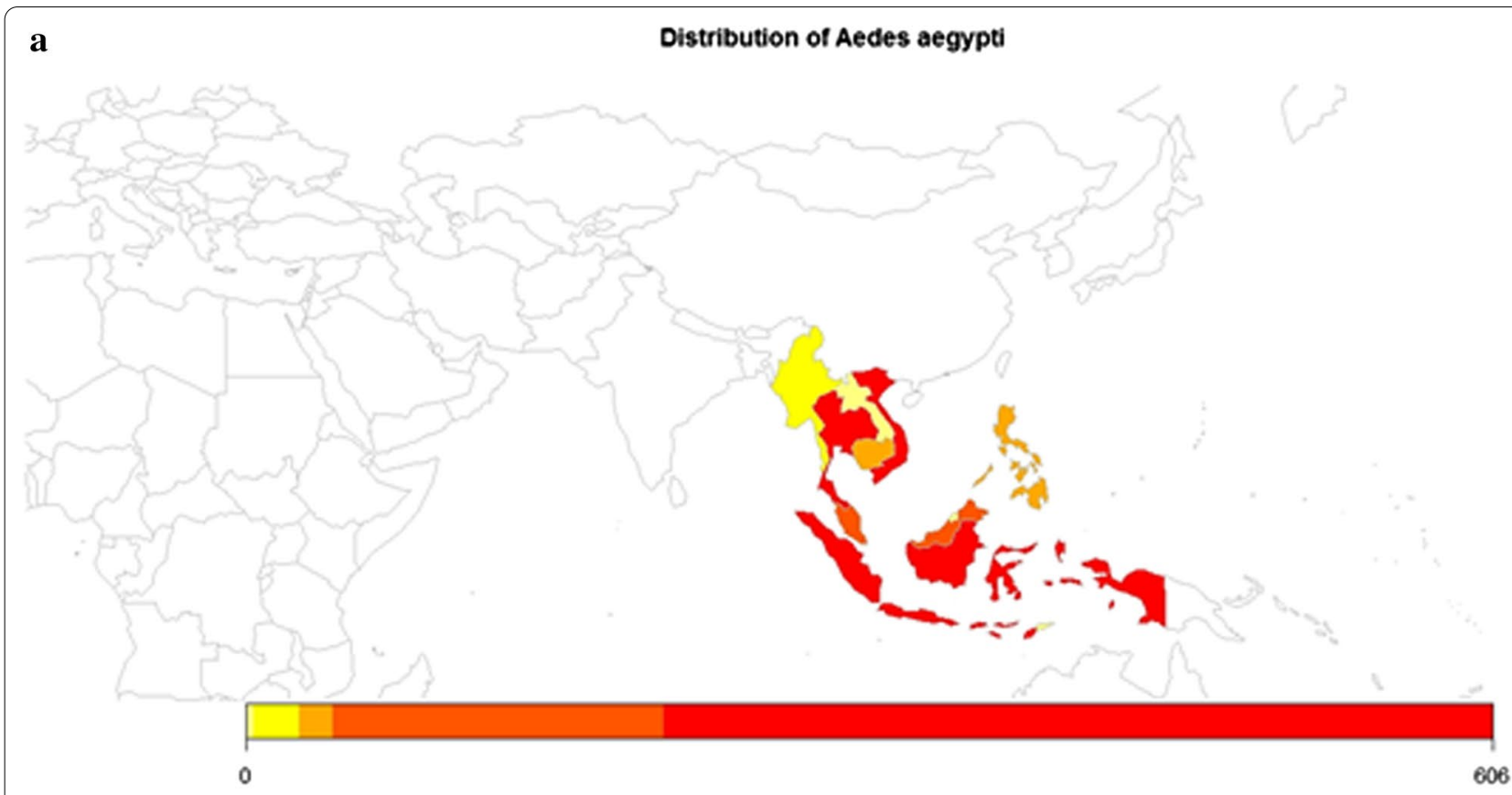

b

Distribution of Aedes albopictus

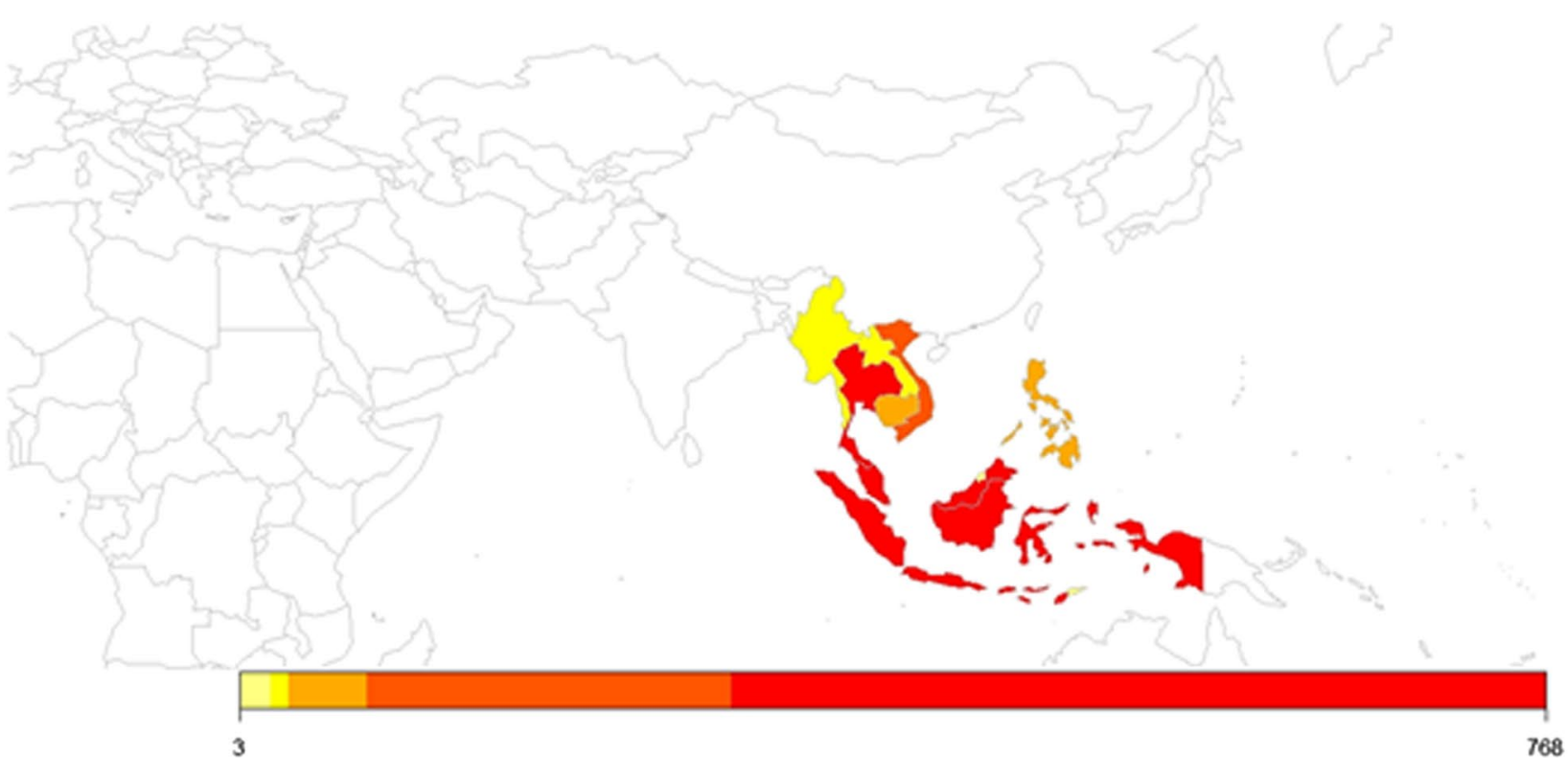

Fig. 1 The occurrence of Aedes aegypti and Aedes albopictus in the Southeast Asia region [5].Yellow - very low; light orange - low; dark orange - moderate and red - high occurrence 
cellular receptors and enters via cell-mediated endocytosis into midgut cells of the host. From the midgut, the viruses disseminate systematically via haemocoel or the body cavity to other secondary tissues, such as the salivary glands [6]. Natural vertical transmission of dengue viruses from the infected females to their offspring has also been reported in many dengue endemic countries [7].

In this paper, we review the distribution of dengue fever from 2000 to 2020 and its associated mortality in each Southeast Asian country. We also gather evidence on the trend of insecticide resistance and its distribution in these countries since 2000, summarising the mechanisms involved. To this end, we searched the PubMed (Medline), Google and Google Scholar databases for articles on insecticide resistance in dengue vectors in Southeast Asia, using the following search terms: 'insecticide susceptible' or 'insecticide resist' or 'pyrethroid resist' or 'insecticide resistance' and 'Southeast Asia' or 'Asia, Southeastern' and 'dengue.' The search was limited to articles in English that had been published between 2000 and 2020 (Fig. 2).

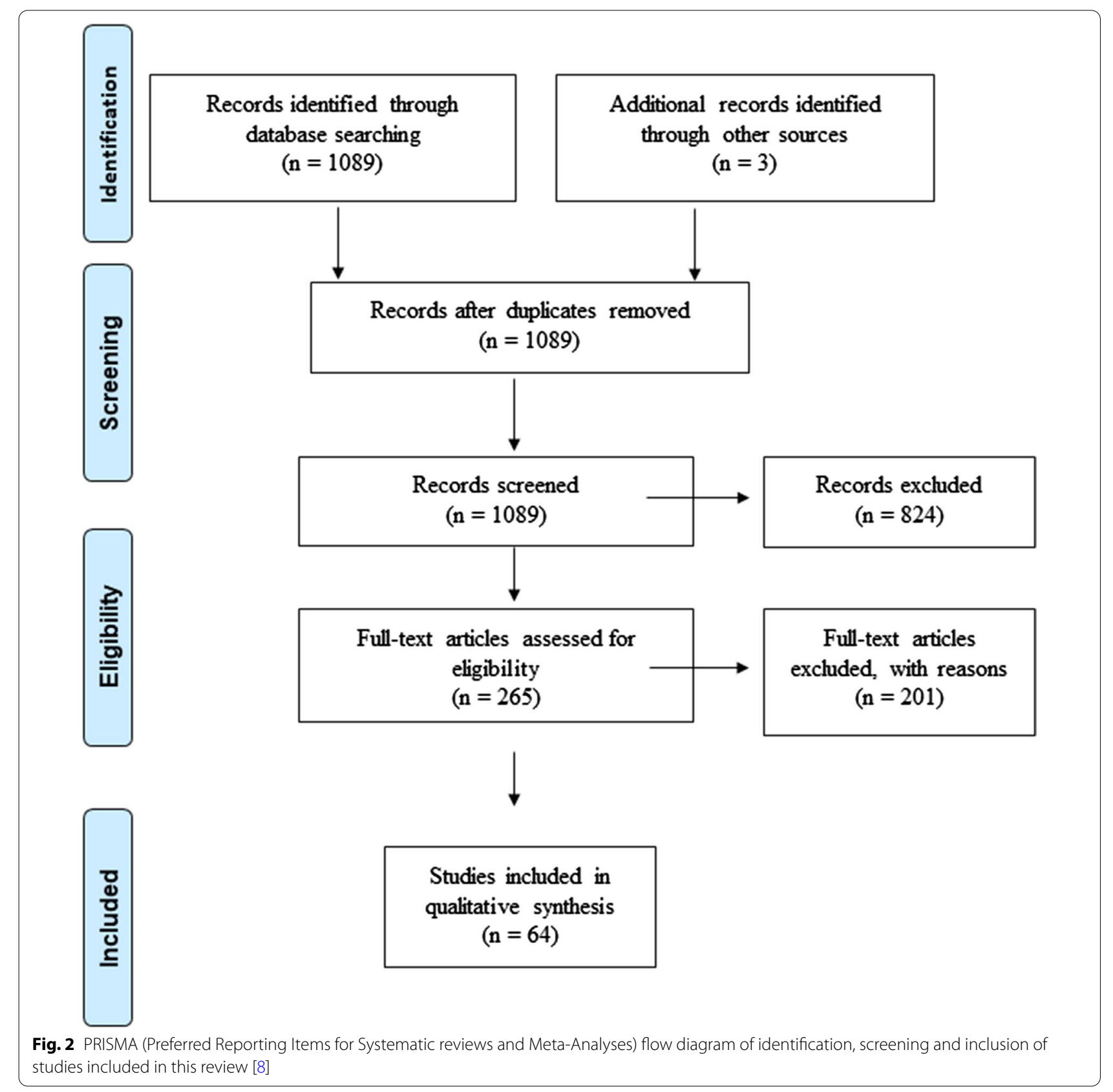




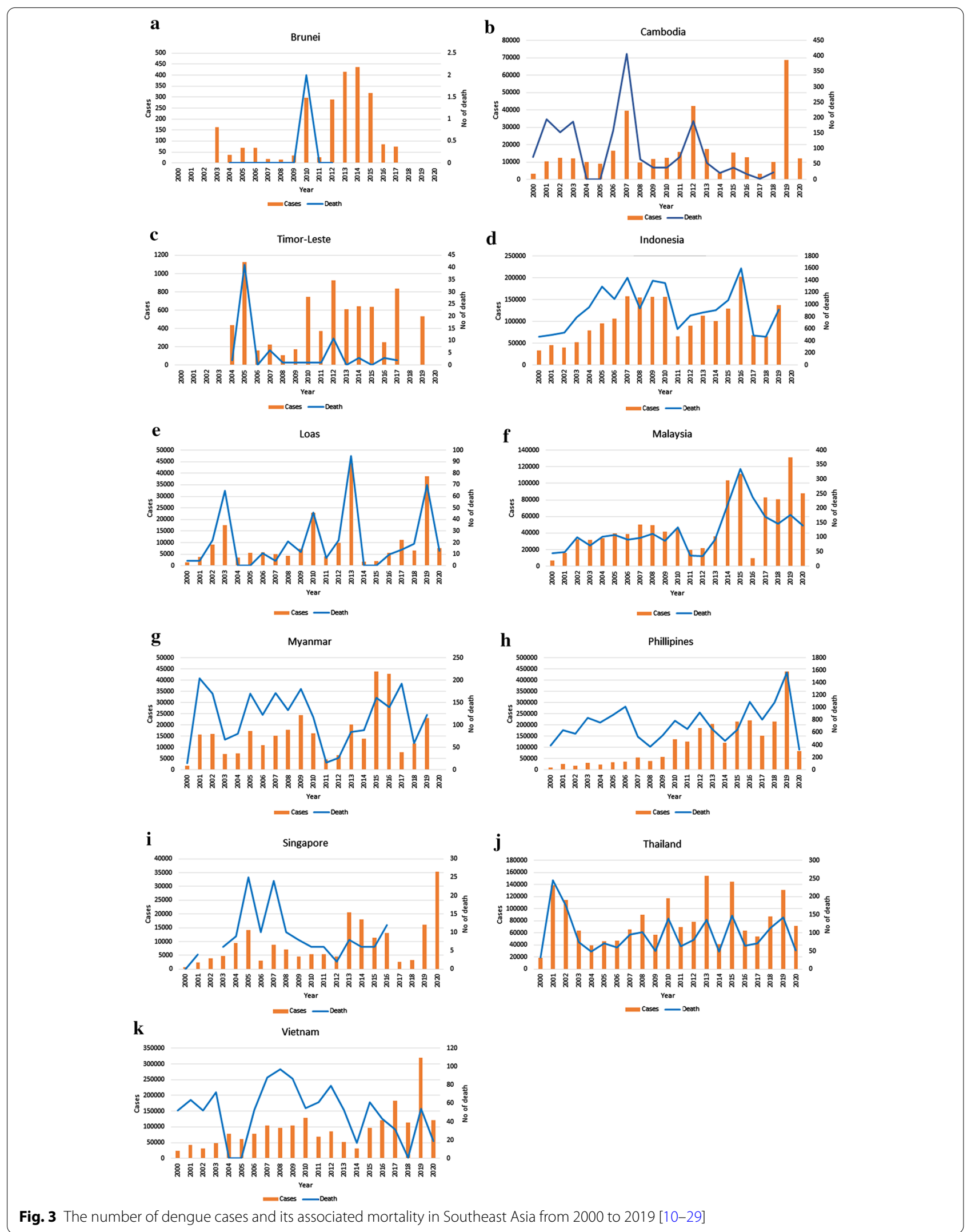




\section{Dengue fever}

Dengue virus can cause symptoms that range from a mild dengue fever to severe deadly dengue haemorrhagic fever and dengue shock syndrome. Annual estimates by Bhatt et al. [9] revealed that the number of dengue cases reported worldwide in 2010 was approximately 390 million, of which 96 million represent apparent dengue infections (dengue haemorrhagic fever or dengue shock syndrome). Asia contributed 67\% (47-94 million infections) to this global disease burden [9]. Most countries in Southeast Asia experience frequent and cyclical epidemics of dengue throughout the year. The prevalence of dengue and its associated mortality for each Southeast Asia country are illustrated in Fig. 3 [10-29].

There is an additional 294 million inapparent infections (mild or asymptomatic) that are not detected by the current health surveillance system [9]. Those persons with inapparent dengue infection may not show any clinical manifestations of typical dengue infections or present with just mild illness that does not require a visit to a healthcare provider or hospitalisation. Hence, the inapparent dengue infection may not be captured as the burden of dengue infection. The prevalence of inapparent dengue is overwhelming and varies by geographical location, time and demography. In Malaysia, the seroprevalence of dengue has been reported to range from 28 to $92 \%[30,31]$, with almost nine out of ten individuals who were dengue-seropositive not recalling having a previous dengue infection [31]. In one study, almost $10 \%$ and $70 \%$ of individuals without any history of dengue infection in Selangor, Malaysia tested positive for immunoglobulins $M$ and $G$ (IgM and IgG), respectively, against dengue virus, and ten out of 11 individuals with dengue viremia were asymptomatic [32]. Currently, the clinical significance of inapparent dengue infections remains undetermined, but it is highly suspected that inapparent dengue plays an important role in the maintenance of dengue transmission in the absence of an epidemic. Blood-feeding experiments with Ae. aegypti mosquitoes revealed that people with asymptomatic and pre-symptomatic DENV infections (low level of viremia) are capable of infecting mosquitoes [33]. In fact, DENV-infected people with no detectable symptoms or before the onset of symptoms are significantly more infectious to mosquitoes than people with symptomatic infections as DENV viraemic individuals without clinical symptoms may be exposed to more mosquitoes through their undisrupted daily routines than sick people. Furthermore, asymptomatic infections account for the bulk of DENV infections, thereby contributing significantly more to virus transmission to mosquitoes than previously recognised. Bosch et al. [34] revealed that people with asymptomatic infections are approximately $80 \%$ as infectious to mosquitoes as their symptomatic counterparts. The clinically inapparent infections may account for $84 \%$ of all dengue transmissions [34], with only $1 \%$ of DENV transmission attributable to people with clinically detected infections after they have developed symptoms.

\section{Insecticides as a control strategy of dengue}

Due to the unavailability of an effective vaccine for dengue, one of the best approaches to control the spread of dengue is by managing the vector and its breeding sites. Various strategic approaches have been promoted to control mosquito vectors, including chemical control (indoor residual spraying, mass fogging, use of household insecticides), biological control (use of mosquito predators, release of specific genetic modified mosquitoes), source reduction and public education. Larvicidal chemicals, such as temephos and Bacillus thuringiensis israelensis (Bti), and adulticidal chemicals in ultra-lowvolume sprays and fogging are widely used to control the spread of the disease. An estimated 2.5 million tons of pesticides are used annually [35]. There are four main classes of insecticides commonly used for vector control programmes: pyrethroids, organophosphates, organochlorines and carbamates.

\section{Organochlorines}

Organochlorines (OCs) are chlorinated hydrocarbons that were developed in the early 1940s, and this category includes dieldrin, lindane, chlorobenziate, chlordane and the most popular chlorinated insecticide of all time, dichlorodiphenyltrichloroethane (DDT) [36, 37]. OCs are effective in controlling malaria, but they persist in the environment as a result of their high lipid solubility [38, 39]. They are subdivided into two subclasses, namely DDT-type chlorinated insecticides and chlorinated alicyclic insecticides, based on their distinct mechanisms and target sites [38]. DDT-type insecticides target the voltage-sensitive sodium channel (Vssc) in mosquitoes. Loughney et al. [40] described that the $\alpha$-subunit of the sodium channel contains four homologous domains (I-IV), with each domain characterised by six transmembrane segments (S1-S6). Segments S1-S4 constitute the voltage-sensing domain whereas segments S5 and S6 form pore domains along with the intervening pore loop. The function of Vssc is to initiate and propagate action potentials in response to membrane depolarisation by opening and closing the channel [41]. DDT exerts its toxicity by impeding the sodium channels, hence retaining the conduction of sodium ions even after membrane repolarisation [42-44]. DDT acts mainly on the peripheral nervous system causing 'DDT jitters' where the muscles twitch throughout the body and the appendages. Exposure to DDT gradually leads to 
excitatory paralysis and subsequent death of the insects [44]. Chlorinated alicyclic insecticides, in comparison, bind at the $\gamma$-aminobutyric acid (GABA) molecule in the GABA chloride ionophore complex, resulting in hyperexcitation of the nervous system that subsequently leads to chlorine channel closure $[45,46]$.

\section{Organophosphates}

Organophosphates (OPs), a phosphoric acid derivative, are the most toxic insecticides and detrimental to both mammals and insects. The most commonly used OPs are malathion, parathion, chlorpyriphos and diazinon. OPs were introduced in the 1960s to replace the usage of OCs with their many adverse effects and long persistence in the environment [39]. OPs interfere irreversibly with acetylcholinesterase (AChE) activity by phosphorylating its serine residues, resulting in hyper-excitation and disruption of neurotransmission in the central and peripheral nervous systems [37, 47]. This enzyme hydrolyses acetylcholine and causes repolarisation of basal plate in neuromuscular connections in preparation for the arrival of the new impulses [37]. Hence, the acute symptoms of poisoning with OP insecticides are muscle cramps, paralysis of respiratory muscles, convulsions and eventually death $[36,48]$.

\section{Carbamates}

Carbamate insecticides are derivatives of carbamic acid. The carbamate insecticides, such as carbaryl, carbofuran, propoxur and aldicarb, exhibit similar effects as the organophosphorus insecticides by inhibiting cholinesterase activity [49]. Nonetheless, the toxic action of carbamates can be reversed whereas the action of OPs is irreversible. In addition, the toxicity of carbamates is rather short as the residue of carbamylated serine is less stable, where decarbamylation tends to split the carbamyl moiety from the enzyme [50].

\section{Pyrethroids}

Pyrethroids are the synthetic analogues of natural insecticidal esters of chrysanthemum acid, called pyrethrins, which are categorised into types I and II based on their physical properties and toxicities. These insecticides have been widely used for the control of disease vectors for more than three decades [51]. The understanding of pyrethroids is complicated by two distinct intoxication syndromes. Type I pyrethroids (permethrin, tetramethrin, allethrin, phenothrin) lack an $\alpha$-cyano group, and exposure causes tremor type syndrome by changing the conformation of the sodium channels for prolonged channel opening [51-53]. On the other hand, type II pyrethroids (cyfluthrin, cyhalothrin, deltamethrin, cypermethrin) possess an $\alpha$-cyano-3-phenoxybenzyl moiety which produces choreoathetosis-salivation syndrome by modulating GABA levels and subsequently affect chlorine channels $[51,53,54]$. Type II pyrethroids have similar effects on sodium channels as type I pyrethroids, but with a lower amplitude of action potential. Type I pyrethroids give rise to repetitive discharges of sodium channels [38]. Previous studies have reported that the neurotoxicity of pyrethroids could be related to abnormal voltage-gated calcium regulation [52]. Certain pyrethroids, including cyfluthrin, cyhalothrin, cypermethrin, deltamethrin and permethrin, promote excessive calcium ion influx due to the reversed sodium-calcium exchange $[51,55]$.

\section{Mechanisms of insecticide resistance}

Massive use of insecticide-based controls has contributed to the development of insecticide resistance, with increased challenges in eliminating Aedes mosquitoes and hence an increased risk of dengue transmission. The mechanism of insecticide resistance may include-but is not limited to-target site resistance, metabolic resistance, penetration resistance and behavioural adaptation (Fig. 4).

\section{Target site resistance}

Target site resistance in mosquitoes is inferred when the targeted site for the action of insecticides is genetically modified, thus limiting its interaction with neurotoxins and consequently eliminating the insecticidal effects. These modifications may include the Vssc mutation, insensitivity of synaptic acetylcholinesterase (AChE1) and mutation in the GABA receptor [56].

\section{Knockdown resistance}

Knockdown resistance ( $k d r$, also known as the Vssc mutation) is the major mechanism of sodium channel insensitivity to both DDT and pyrethroids $[57,58]$. Most Vssc mutations are located at domains IS6, IIS6 and IIIS6. $k d r$ caused by point mutations of the target site, with the substitution of leucine (L) by phenylalanine (F), histidine $(\mathrm{H})$ or serine $(\mathrm{S})$ in Vssc in IIS6 at codon 1014, has been reported in mosquitoes of genera Anopheles and Culex [59]. In Ae. aegypti mosquitoes, various pyrethroids/ DDT resistance-associated mutations (G923V, L982W, I1011M/V, V410, T1520I, S989P, F1534S/L/C, D1763Y, V1016G/I) have been documented [60-64]. For example, the T1520L mutation was identified in Ae. aegypti populations from India and the V1016G mutation in Ae. aegypti populations from Malaysia and Thailand [6567]. In addition, co-occurrence of multiple $k d r$ mutations has been commonly associated with higher levels of phenotypic resistance to DDT and pyrethroids [68, 


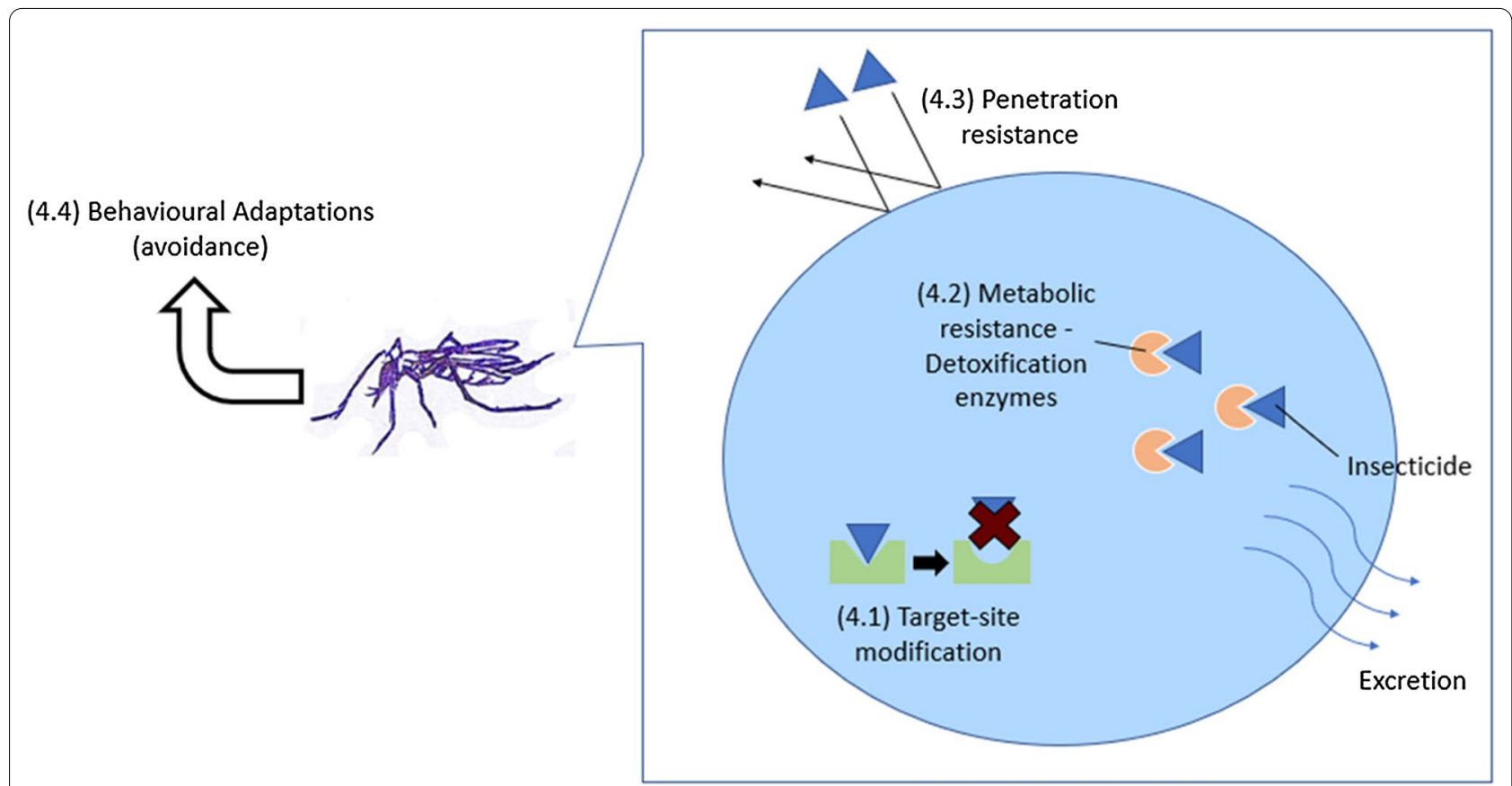

Fig. 4 Mechanism of insecticide resistance i.e. target site resistance (4.1), metabolic resistance (4.2), penetration resistance (4.3) and behavioural adaptation (4.4)

69]. Co-existing mutations of V1016G/S989P have been reported in Malaysia, Thailand and other Southeast Asia regions, and co-existing mutations of V1016G/F1534C were found in Singapore in Ae. aegypti populations [66, 70, 71]. Vssc mutations can also confer cross-resistance between DDT and pyrethroids due to reduced sensitivity of the nervous system [72, 73]. It is remarkable that Vssc mutations have expanded greatly over the last three decades (Table 1) but that the specific mutations that confer the resistance have yet to be identified.

\section{Synaptic AChE insensitivity}

Acetylcholinesterase is the primary target of $\mathrm{OP}$ and carbamate insecticides which block the transmission of nerve impulses at cholinergic synapses. An understanding of $\mathrm{OP}$ and carbamate resistance is demonstrated by the insensitivity of AChE subsequent to amino acid substitutions at the target gene, acetylcholinesterase 1/2 (ace-1 or ace-2) [80, 81]. To date, only three amino acid substitutions have been described in different mosquitoes species: the substitution of glycine to serine at codon 119, of phenylalanine to valine at codon 290 and of phenylalanine to tryptophan at codon 331 [80-83] (Table 2). For example, the G119S mutation has been extensively studied in Culex pipiens and Anopheles gambiae, but the involvement of the ace gene on insensitive $\mathrm{AChE}$ in certain mosquito species, including Ae. aegypti and
Anopheles stephensi, remains to be identified. G119S substitution results in steric hindrance, which reduces substrate or inhibitor binding, whereas F290V and F331W both modify the stabilisation process [84]. The G119S mutation occurs in the oxyanion hole of acetylcholinesterase 1 which aids in substrates trafficking [84, 85]. The F290V mutation involves substrate specificity and the F331W mutation has been denoted as being involved in substrate guidance and binding [80, 86, 87].

\section{GABA receptor resistance}

The GABA receptor is encoded by the resistance to dieldrin $(R D L)$ gene involved in neuronal signalling [88]. The RDL receptor is a member of Cys-loop ligand-gated ion channel superfamily with a N-terminal extracellular domain for GABA binding. This receptor contains five subunits, with each subunit having an extracellular cysteine loop and four transmembrane domains (M1M4) [89]. RDL is the target of various insecticides, such as cyclodiene, fipronil and pyrethroids, where its function is influenced by the post-translational modifications $[88,90]$. Several findings suggest that the complexity of RDL receptors is formed by alternative splicing at axons 3 and 6 and RNA editing [91]. Here, adenosine residues are replaced with inosine in transmembrane segment M2 of $R D L$ through the action of adenosine deaminases, resulting in the removal of the amine group and subsequently leading to formation of different isoforms. Studies by 
Table 1 Knockdown resistance (Vssc) mutations that have been detected in different mosquito populations

\begin{tabular}{llll}
\hline Mutation & $\begin{array}{l}\text { Transmembrane } \\
\text { domain }\end{array}$ & Mosquito & References \\
\hline G923V & $\|$ & Aedes aegypti & {$[61]$} \\
L982W & $\|$ & Ae. aegypti & {$[61]$} \\
I1011M & $\|$ & Ae. aegypti & {$[61]$} \\
I1011V & $\|$ & Ae. aegypti & {$[74]$} \\
V410L & I & Ae. aegypti & {$[75]$} \\
T1520I & III & Ae. aegypti & {$[65]$} \\
S989P & $\|$ & Ae. aegypti & {$[63]$} \\
F1534S & III & Ae. albopictus & {$[76]$} \\
F1534L & III & Ae. albopictus & {$[76]$} \\
F1534C & III & Ae. albopictus, Ae. aegypti & {$[75,77]$} \\
D1763Y & IV & Ae. aegypti & {$[78]$} \\
V1016G & $\|$ & Ae. aegypti & {$[63]$} \\
V1016I & $\|$ & Ae. aegypti & {$[79]$} \\
\hline VssCVotage & &
\end{tabular}

Vssc Voltage-sensitive sodium channel

Table 2 Acetylcholinesterase mutations observed in different mosquito populations

\begin{tabular}{llll}
\hline Mutation & Gene & Mosquitos & References \\
\hline G119S & ace-1 & $\begin{array}{c}\text { Culexpipiens, Culex vishnui, Anopheles } \\
\text { gambiae and Anopheles albimanus }\end{array}$ & {$[80-82]$} \\
F290V & ace-1 & C.pipiens & {$[83]$} \\
F331W & ace-2 & Culex tritaeniorhynchus & {$[82]$} \\
\hline
\end{tabular}

ace-1/ace-2 Acetylcholinesterase $1 / 2$

Taylor-Wells et al. [88, 92] have documented the identification of species-specific RNA A-to-I editing sites in the RDL of insecticide-resistant mosquitoes. For example, an alanine to serine or glycine substitution at position 296 is found in Ae. aegypti [56] and Ae. albopictus [93]. This mutation does not affect insecticide sensitivity but it does reduce the fitness as a result of the A296G substitution which greatly impacts neuronal signalling [88].

\section{Metabolic resistance}

Resistant strains detoxify the toxins/insecticides much better than susceptible mosquitoes due to the overexpression of or conformation change in enzymes subsequent to point mutations in cis/trans loci of the enzymes [94]. Metabolic detoxification is usually associated with three major enzymatic activities, such as cytochrome P450 monooxygenases, esterases and glutathione S-transferases (GST) activity [56, 60, 95].

\section{P450 monooxygenases}

Cytochrome P450 (CYP) monooxygenases are one of the primary resistance mechanisms of pyrethroids in mosquitoes. CYP is a hydrophobic, heme-containing enzyme which metabolises a number of exogenous and endogenous compounds via oxidation in the presence of NADPH-CYP reductase (CPR) and occasionally cytochrome b5 [56, 96]. Overexpression of CYPs or mutation at an open reading frame of CYPs have been reported in insecticide-resistant mosquitoes [97, 98]. The details of the molecular mechanisms are poorly characterised due to the presence of large number of CYPs. Table 3 summarises the known overexpressed CYPs and their associated insecticide resistance in Aedes mosquitoes. In Ae. aegypti, CYP6Z8 plays a pivotal role in pyrethroid clearance via carboxyesterase-mediated hydrolysis that generates 3-phenoxybenzyl alcohol (PBAlc) and 3-phenoxybenzaldehyde (PBAld), and finally 3-phenoxybenzoic acid (PBAcid), all with lower toxicity to the mosquitoes as compared with intact pyrethroids $[105,108,109]$.

\section{Esterases}

Esterase-mediated resistance to OPs, pyrethroids and carbamates have been studied extensively in Culex mosquitoes. Esterases act by rapid binding or slow turning, i.e. sequestration, to prevent the interactions between insecticides and AChEs [110]. Furthermore, increased production of esterases was reported to be closely related with amplification of the esterase alpha 2 genes [111, 112]. Two genes, est $\alpha 2$ and est $\beta 2$, are involved in detoxifying carboxylester hydrolase expression and esterase overproduction [113]. Both of them hydrolyse the ester bonds to produce alcohols and acids as metabolites via a two-step reaction which involves nucleophilic attack of the serine residue on the carbonyl carbon of the ester bond, followed by a second nucleophilic attack by water molecules to replace the acyl group, resulting in the release of the free active enzyme and acidic moiety of the carboxylic ester $[114,115]$. These two loci are differentially transcribed with average ratios of est $\beta 2$ over est $\alpha 2$ at 10:1 and 15.9:1, respectively, in all resistant Culex mosquitoes [116]. Enhanced esterase activities in insecticideresistant Ae. aegypti has been reported but the genes involved are yet to be identified [117].

\section{Glutathione S-transferase activity}

Glutathione $S$-transferases belong to a large and multifunctional enzyme family participating in detoxification of xenobiotics, such as insecticides. They are classified into two ubiquitously distant classes: microsomal and cytosolic GSTs, respectively. Microsomal GST has a trimeric structure and its associated mechanism of insecticide resistance has yet to be elucidated. On the other hand, insect cytosolic GSTs are dimeric proteins comprising two subunits of $24-28 \mathrm{kDa}$ each $[56,118]$. 
Table 3 Increased cytochrome P450 expression in various mosquito populations against insecticides

\begin{tabular}{|c|c|c|c|c|}
\hline Mosquitos & CYPs & Stage & Insecticide & References \\
\hline Ae. aegypti & CYP4H28 & Larvae & Temephos & [99] \\
\hline Ae. aegypti & CYP6AH1 & Larvae & Temephos & {$[99]$} \\
\hline Ae. aegypti & CYP6CB1 & Adults & Permethrin & [100] \\
\hline Ae. aegypti & CYP6F3 & Larvae & Permethrin & [101] \\
\hline Ae. aegypti & CYP6M6 & Larvae and adults & Deltamethrin & {$[102,103]$} \\
\hline Ae. aegypti & CYP6M10 & Larvae & Permethrin & {$[101]$} \\
\hline Ae. aegypti & CYP6M11 & Larvae & Permethrin, Temephos & {$[102,103]$} \\
\hline Ae. aegypti & CYP6N12 & & Temephos & [104] \\
\hline Ae. aegypti & CYP6Z6 & Larvae and adults & Deltamethrin & {$[102,103]$} \\
\hline Ae. aegypti & CYP6Z8 & Larvae and adults & Deltamethrin, Temephos & {$[99,102,103,105]$} \\
\hline Ae. aegypti & CYP9J10 & Adults & Permethrin & {$[100]$} \\
\hline Ae. aegypti & CYP9J19 & Adults & Permethrin & {$[100]$} \\
\hline Ae. aegypti & CYP9J22 & Larvae and adults & Deltamethrin & {$[102,103]$} \\
\hline Ae. aegypti & CYP9J23 & Larvae and adults & Deltamethrin & {$[102]$} \\
\hline Ae. aegypti & CYP9J24 & Adults & Permethrin & {$[100,106]$} \\
\hline Ae. aegypti & CYP9J26 & Adults & Permethrin & {$[100,106]$} \\
\hline Ae. aegypti & CYP9J27 & Adults & Permethrin & {$[100]$} \\
\hline Ae. aegypti & CYP9J28 & Adults & Permethrin & [101] \\
\hline Ae. aegypti & CYP9J32 & Adults & Deltamethrin, Permethrin & {$[100,106]$} \\
\hline Ae. aegypti & CYP12F6 & Adults & Permethrin & {$[100]$} \\
\hline Ae. aegypti & CYP304C1 & Adults & Permethrin & {$[100]$} \\
\hline Ae. Albopictus & CYP6AG6 & Adults & Deltamethrin, Permethrin & [107] \\
\hline Ae. albopictus & CYP6N3 & Adults & Bendiocarb & [107] \\
\hline Ae. albopictus & CYP6P12 & Adults & Deltamethrin, Permethrin & [107] \\
\hline Ae. albopictus & CYP6Z6 & Adults & Deltamethrin, Permethrin & {$[107]$} \\
\hline
\end{tabular}

Another group of GSTs (kappa GSTs) are located in mammalian mitochondria and peroxisomes, but this class of GSTs is absent from insects [119, 120]. Hence, only cytosolic GSTs have been implicated in insecticide resistance to date. A total of 26 GST genes have been reported in Ae. Aegypti, of which two can splice alternatively, which results in a total of 29 transcripts for cytosolic GSTs [121]. Mechanisms of GST-mediated insecticide resistance have been depicted as occurring either directly via the GST conjugation reaction (phase I) or via metabolism of secondary products by other detoxifying enzymes, such as P450 (phase II) [122]. In phase I metabolism, GSTs catalyse the nucleophilic attack of the thiol group of reduced glutathione located in the electrophilic centre of lipophilic compounds, including OPs and pyrethroids, causing increased water solubility and excretion by the cells $[118,122$, 123]. Another GST-based detoxification occurs when GSTs serve as a co-factor of dehydrochlorination by removing a hydrogen atom from its substrate [124]. This reaction has been implicated in resistance to DDT. In addition, certain GSTs confer resistance by passive binding or detoxifying lipid peroxidases and reactive oxygen species subsequent to the induction of oxidative stress $[117,119,123,124]$.

To date, there are at least six classes of GSTs in $A e$. aegypti (theta, sigma, zeta, omega, delta and epsilon) [125]. GSTE2 in the Epsilon class is overexpressed in DDT-permethrin-resistant Ae. aegypti [126].

\section{Penetration resistance}

Penetration resistance occurs when barriers develop at the outer cuticle of mosquitoes, resulting in slow absorption of insecticides into their bodies. Likewise, resistant mosquitoes absorb toxins at a much slower rate than susceptible strains. Reduced penetration in turn provides more time for detoxification by facilitating the action of metabolic enzymes. Thus, this cuticular resistance is usually involved in cross-resistance to multiple insecticides due to their lipophilic property [127]. Overexpression of CYP enzymes, including CYP4G16 and CYP4G17, facilitates the deposition of cuticular hydrocarbons in the epicuticle of the pyrethroid-resistant mosquitoes, such as Ae. aegypti [128, 129]. Hence, large amounts of cuticular hydrocarbons are formed and deposited on top of cuticle that function as a waterproofed layer conferring 
desiccation resistance. This mechanism on lipid transport and epicuticular deposition is the least understood of all the mechanisms described herein and should be further investigated to define its role in insecticide resistance.

\section{Behavioural adaptation}

Mosquitoes can reduce or prevent negative consequences of insecticides through adaptations. Behavioural resistance is generally categorised into temporal, spatial and trophic avoidance whereby the mosquitoes escape from coming into contact with insecticides. The term 'temporal avoidance' involves a mosquito reducing its risk of exposure by mismatch to the timing when insecticides are employed whereas 'spatial avoidance' involves the mosquitoes moving away from the insecticide-treated areas [130, 131]. Mosquitoes apply trophic avoidance by avoiding feeding on hosts in areas where insecticides are extensively used $[130,131]$. Therefore, many researchers have hypothesised that behavioural changes may also be considered as a mechanism of resistance. In addition, behavioural tolerance evolves when mosquitoes that are unable to escape from the exposure develop tolerance through limiting their fitness loss. Mosquitoes can alter their behaviours by increasing their current reproductive effort, such as adjusting their egg production patterns, reducing their energy expenditure and maximising their nutrient uptake [132]. This proposed theoretical classification of behavioural resistance is poorly deciphered and the fitness costs are yet to be quantified.

\section{Prevalence of insecticide resistance in Southeast Asia}

Various insecticides have been used worldwide for the control of the vector-borne diseases, including dengue. However, the effectiveness of this measure in controlling Aedes mosquitoes needs to be considered in light of the increasing trends of resistance towards different insecticides at different geographical locations. Studies on insecticide resistance and its prevalence in Aedes mosquitoes may be limited or insufficient in certain Southeast Asian countries. The summary of the studies on the prevalence of insecticide resistance in all of the Southeast Asian countries included herein is provided in Additional file 1: Table S1.

\section{Cambodia}

Dengue fever is a major public health issue in Cambodia, with an estimated 185,000 cases in that country annually [133, 134]. The application of large amounts of insecticides was initially effective in decreasing the number of dengue cases, but despite the little information currently available, the incidence of insecticide resistance can be seen to be increasing. In Cambodia, temephos is used to control larvae whereas deltamethrin and permethrin are used as adulticides. Recently, resistance of Cambodian Ae. aegypti populations to temephos has been appearing in Phnom Penh, Battambang and Kampong Cham, where the resistance ratios were reported to be 5.3, 33.6 and 8.4 in urban areas and 5.3, 13.0 and 11.2 in rural areas, respectively (a ratio $>5$ is an indication of resistance) [134, 135]. Fortunately, Ae. aegypti larvae remain susceptible to temephos in both urban and rural areas in Siem Reap [133]. Boyer et al. [133] reported strong resistance to permethrin, with an average mortality rate of $2.22 \%$, and a lower resistance to deltamethrin, with a mortality percentage of $<90 \%$. The V1016G, S989 and C1534C mutations have also been detected in Cambodia in Ae. aegypti populations at a high frequency $[136,137]$.

\section{Indonesia}

In 2018, 65,602 cases of dengue fever were reported, of which 467 were fatal [29]. Low mortality rates of $A e$. aegypti larvae (0-1.33\%) were observed in several cities against malathion insecticide, possibly due to the massive use of malathion in fogging for past three decades [138]. Aedes aegypti larvae from Surabaya, Indonesia were reported to be resistant to temephos, with moderate mortality rates ranging from 16 to $60 \%[138,139]$. Knockdown resistance against pyrethroid insecticides was associated with V1023G and S996P mutations in Ae. aegypti larvae in Yogyakarta, and with the S989P and V1016G mutations in Denpasar, Bali [140, 141]. Adult Ae. aegypti that were resistant to pyrethroids carried Vssc gene mutations. Three point mutations (V1016G, F1534C and S989P) were associated with pyrethroid resistance [137, 142, 143]. Permethrin resistant Ae. aegypti from Makassar, Sulawesi, Indonesia were associated with the V1016G mutation [144]. Ae. aegypti populations obtained from Padang Jati and Gunung Pangilun were resistant to temephos. A point mutation at ace-1 of these temephosresistant Ae. Aegypti strains collected from Padang did not have the G119S substitution, but instead had the T506T substitution, a silent mutation [145].

Other than target site resistance, the mechanism of action could also involve metabolic detoxification. Increased levels of detoxifying enzymes, such as GSTs, oxidases and esterases, play important roles in conferring resistance to DDT, malathion, temephos or pyrethroids in mosquitoes collected from Bogor, Garut, Sumedang, Tasikmalaya or Sumerang, Indonesia [146]. For example, exposure of Sumedang mosquito populations to permethrin resulted in a 17-fold elevation of esterase activities and a fourfold elevation of mixed function oxidases [146]. These mosquitoes were significantly associated with the V1016G and S989P mutations [147]. Mosquitoes from Denpasar, Mataram, Kuningan, Padang, Samarinda and 
Sumba Timur were resistant to D-allethrin, transfluthrin and metofluthrin of the mosquito coils [148]. Nevertheless, susceptible strains were detected in Pontianak, Dompu and Manggarai Barat [148].

\section{Laos}

Dengue is re-emerging in Laos, with several reported outbreaks between 2013 and 2017 in both rural and urban areas. The number of cases annually range from 2000 to 20,000 , of which approximately ten are fatal. OCs such as DDT were used for vector control and agriculture in Laos from the 1950s until they were banned in 1989. The larvicide temephos, an OP, was first used to treat water in containers during the dengue outbreak in 1987. Malathion was then introduced in the 1990s for thermal fogging, followed by the use of pyrethroids (deltamethrin and permethrin) from early 2000 s onwards.

Tangena et al. [149] reported that all Ae. albopictus collected from the capital city Vientiane and Luang Prabang province were resistant to DDT (27-90\% mortality) and malathion (20-86\% mortality) and susceptible to deltamethrin and permethrin (100\% mortality), with the exception of one population from Kao-gnot, Vientiane City which was suspected of being resistant to permethrin (96\% mortality). Ae. albopictus larvae were highly resistant to DDT (3-44\%), and showed resistance to temephos in Luang Prabang (Huayhoy village, 74\% mortality) and Vientiane City (Suanmone and Oudomphon, 42 and $87 \%$ mortality, respectively) [149].

Marcombe et al. [150] investigated insecticide resistance in Ae. aegypti populations collected from 11 villages located in five provinces in Laos to larvicides and adulticides used in Laos. All Ae. aegypti larvae collected showed moderate to strong resistance to temephos, deltamethrin, permethrin and DDT. Similarly, the adult mosquitoes collected from most of the villages were highly resistant to DDT, permethrin and malathion but susceptible to deltamethrin. All resistant adult mosquitoes showed significant elevated CYP monooxygenases, GST and carboxylesterases. Two $k d r$ mutations at V1016G and F1534C were detected in these populations, and a higher frequency of the F1543C $k d r$ mutation $(>0.6)$ and low frequency of V1016G mutation $(<0.36)$ were found in resistant strains [150].

Marcombe et al. [151] conducted a simulated field trial of temephos, $B t i$, diflubenzuron, pyriproxyfen and spinosad using an established Ae. aegypti colony (IPL strain) obtained from wild, field-caught mosquito larvae collected using ovitraps placed at the Institut Pasteur du Laos (IPL), Vientiane in Kao-gnot village. This wild IPL field strain was susceptible to Bti, diflubenzuron and pyriproxyfen (resistance ratio $[R R]=1$ ) but showed moderate resistance to temephos and spinosad $(R R<5)$. These results suggest that $B t i$, diflubenzuron and pyriproxyfen may be used as alternative larvicides for dengue vector control in water-storage containers in Laos at places with temephos-resistant mosquito populations.

\section{Malaysia}

As of 12 December 2020, a cumulative 88,074 dengue cases had been reported in Malaysia, which marks a drastic decrease compared with the 124,777 cases for the same period in 2019 [15]. Studies have been conducted in all 13 states to evaluate the status of insecticide resistance in the dengue vectors and the associated resistance mechanisms. Rosilawati et al. [152] conducted a comprehensive study on 12 dengue hotspots across five states in Peninsular Malaysia and revealed that $75 \%$ of the collected Ae. aegypti mosquitoes were resistant to permethrin. In particular, Ae. aeygpti from Bandar Baru Bangi (S15) exhibited higher knockdown rate of 600-folds compared with laboratory strains [152]. Rosilawati et al. [152] extended their study with another three dengue-endemic localities and characterised the resistance mechanisms in Ae. aegypti. All three field-collected strains exhibited strong resistance to pyrethroids with complete absence of mortality but were highly susceptible to OPs. Similarly, Ae. aegypti larvae collected in Selangor and Penang also showed same resistant patterns [153-155]. Other than pyrethroids, Ae. aegypti populations were also resistant to DDT and carbamate bendiocarb. Resistance profiles were associated with $k d r$ mutations in Malaysian Ae. aeygpti populations. Most of these strains harboured the F1534C, V1016G and V1023G substitution alone or combination mutations of V1023G and S996P $[66,153,156]$.

On the other hand, Ae. albopictus populations, secondary vectors of dengue, were found to be mostly fully susceptible to pyrethroids, with Kuala Lumpur strains showing a moderate tolerance to deltamethrin and permethrin [66]. In that study, variation in the mortality rates of Ae. albopictus to DDT, bendiocarb, dieldrin and malathion in several states was reported and both Aedes species exhibited elevated levels of CYP and oxidase enzymes [66]. Ishak et al. [107] reported overexpression of CYP6P4 in Ae. albopictus and CYP6P12 in Ae. aegypti as being associated with pyrethroid resistance whereas CYP6N3 was observed across DDT- and carbamateresistant Ae. albopictus populations. Several CYP genes, including CYP9J27, CYP9J26, CYP9J28, CYP9M6 and CYP6CB1, were found to be overexpressed in pyrethroidresistant Ae. aegypti [157]. Overexpression of cuticular protein genes, which results in cuticle thickening, was associated with reduced penetration of pyrethroid in Ae. albopictus populations [107].

Research on insecticide resistance in East Malaysia is limited. Larvicide resistance in Ae. albopictus was 
reported in Sabah, particularly on the West Coast and in Kudat were strong resistance to DDT and malathion with complete survival, and to tempehos and bromophos with mortality rates ranging from 0 to $93.33 \%$ were observed [158]. Adult Ae albopictus populations were susceptible to pyrethroids but displayed moderate resistance against the other three classes of insecticides in Sabah [159]. The prevalence of Ae. albopictus populations in Sabah could be explained by its geographical landscape of tropical rainforests, which is a favourable habitat for Ae. albopictus.

\section{Myanmar}

The Ministry of Health and Sports reported 4121 cases of dengue fever with 32 deaths across Myanmar as of 11 July 2020 [26]. A small number of studies on the mechanisms of pyrethroid resistance in Ae. aegypti were reported in Myanmar. F1534C mutations were detected in permethrin-resistant Ae. aegypti in Yangon City [136]. Single point mutations of V1016G and S989P together with the co-occurrence of $k d r$ mutations were observed in pyrethroid-resistant Ae. aegypti [160]. Three patterns of co-occurrence were observed, including V1016G/ F1534C, V1016G/S989P and V1016G/F1534C/S989P, at varying frequencies of $2.9,65.7$ and $0.98 \%$, respectively [160]. A genotyping study also revealed the presence of the wildtype VV/FF, double homozygous alleles (GG/ $\mathrm{CC}$ ), VG/CC and GG/FC derived from the F1534C and V1016G mutations in Yangon City [137]. DDT resistance, with less than $5 \%$ of mortality, was reported in Aedes mosquitoes collected at seven townships in Yangon City where 1.2 metric tons of DDT had been employed for dengue fever control until it was banned in 2003 [161].

\section{Philippines}

In the Philippines, 420,000 dengue cases were reported in 2019 , of which 1565 were fatal, which is double the number of cases reported the previous year for the same period [15]. Aedes aegypti collected from Mandaluyong City were only susceptible to malathion but resistant to all other insecticides [162]. To date, there is no report on insecticide resistance for both larvae and adults of Aedes mosquitoes in Philippines.

\section{Singapore}

The National Environment Agency of Singapore disclosed a total of 701 dengue cases transmitted by Aedes mosquitoes as of 2 February 2021, which twofold lower than the number of cases during same period of the previous year [22]. Ae. aegypti mosquitoes in Singapore were reported to be resistant to permethrin and cypermethrin decades ago [163]. Similar to other countries, DDT and pyrethroid resistance among Ae. aegypti larvae and adult mosquitoes has been reported in Singapore [164, 165]. Vssc mutations were detected in pyrethroid- and DDT-resistant Ae. aegypti carrying the V1016G, F1534C and F1269C substitutions [71, 128], with the G1016 alleles contributing more significantly to the target site insensitivity than the $\mathrm{C} 1534$ alleles [128]. A combination of V101G, S989P and F1534C mutations modified the sensitivity of Vssc channels to deltamethrin and permethrin by 90 - and 1100 -fold, respectively [166]. A correlation between $C Y P$ genes, i.e. overexpression of $C Y P 6 B B 2, C Y P 9 M 6, C Y P 9 M 4$, CYP9M5, CYP4C50, CYP6Z7, CYP6Z8 and CYP6F3, and permethrin resistance was detected [128]. Elevated esterase and GST levels may play an important role in pyrethroid and DDT resistance [164, 165]. F1534C alleles were detected in permethrin-resistant Ae. albopictus [167]. An association between high levels of mixed function oxidase and permethrin resistance has also been detected in Ae. albopictus populations [163].

\section{Thailand}

Thailand reported 129,906 dengue cases in 2019 [17]. The susceptibility status and the resistance mechanisms of mosquitoes in Thailand are the most well-studied among the nations of Southeast Asia. In recent years, the tremendous use of all four classes of insecticides has resulted in an irreversible consequence, namely the development of insecticide-resistant mosquito strains, with Ae. aegypti populations in Thailand reported to be resistant to a wide range of insecticides, including deltamethrin, permethrin, fenitrothion, temephos, propoxur, DDT, cyfluthrin and alpha-cypermethrin $[67,168-170]$. The Vssc mutation is the major mechanism of pyrethroid resistance, in which V1016G was detected to be associated with the S989P and F1534C substitution in the homozygous form $[136,166]$. Additionally, triple heterozygous P989, G1016 and C1534 mutants were detected in deltamethrin-resistant mosquitoes [137, 171]. Another mutation, F1552C, was also detected in permethrin-resistant strains in several provinces of Thailand, including Chiang Mai, Song Khla and Ubon Rachathanee [172]. Metabolic detoxification was also found to be involved in insecticide resistance with an increased expression of monooxygenases (CYP9J32, CYP6Z8, CYP9M9, CYP6AH1, CYP4H28), GSTs (GSTE2) and carboxylesterases (CCEAE3A, CCE$A E 4 A$ and CCEAE6A) detected in resistant Ae. aegypti [99, 106, 173, 174]. Ae. albopictus samples collected from Pong Nom Ron showed high resistance to all five pyrethroids, with mortality rates ranging from 34.4 to $68.6 \%$. Rayong strains also showed resistant to permethrin with a $51 \%$ mortality rate [175]. 


\section{Timor-Leste}

Timor-Leste reported 837 dengue cases in 2017, of which two were fatal [24]. Insecticide resistance resulting in ineffectiveness of dengue elimination was only reported once, in 2015. Ae aegypti populations from Dili were found to be resistant to permethrin, lambda cyhalothrin and resmethrin in association with the overexpression of esterases [176].

\section{Vietnam}

Dengue infections have increased substantially in Vietnam with 121,398 reported cases and 19 deaths as of 29 November 2020 (vs 314,468 cases and 54 deaths in 2019) [15]. The resistance of Ae aegypti to DDT and pyrethroids was first reported in 1999 [177]. $k d r$ mutations and overexpression of CYP enzymes in resistant $A e$. aegypti populations were observed. Ae. aegypti resistant to permethrin has been reported in several provinces, including Nha Trang, Hanoi, Ho Chi Minh, Kien Giang, Dong Nai and Dak Lak, with mortality rates ranging from 3.03 to $52.25 \%$ [178]. In addition, Ae. aegypti mosquitoes were found to be resistant to lambda-cypermethrin, cyfluthrin, etofenprox, DDT and alpha-cypermethrin $[178,179]$. Several point mutations (V1016G, V1016I and F1269C) were detected [178, 180]. V1016G mutations were also detected in permethrin-resistant Ae. albopictus populations from Hanoi [167].

\section{Brunei}

To date, there is no or limited access to dengue data and resistance for Brunei.

\section{Conclusions and future perspectives}

Although insecticides were once effective in controlling mosquito-borne diseases, the increasing trends of mosquito-borne diseases may indicate an increasing resistance to or ineffectiveness of insecticides in controlling the transmission of the diseases. Furthermore, insecticides may also significantly influence the environment and ecosystems. It may be wise to revisit the concept of using chemical insecticides for controlling or eliminating mosquitoes and hence disease transmission. Longlasting insecticide nets (LLINs) and indoor residual spraying, the use of which has been implemented as public health intervention tools for mosquito control, now require more diversified products due to the overwhelming development of insecticide resistance among mosquito populations. Biological control strategies which target different stages of the mosquito life-cycle, such as the use of numerous copepods, including Mesocyclops longisetus and $M$. thermocyclopoides which prey on the young mosquito instars, could be an alternative control strategy[181, 182]. In Vietnam, copepod biocontrol has been undertaken for decades to target $A e$. aegypti but it is challenging to apply the copepods as most of the larval habitats are not favourable habitats for these copepods [183, 184]. Other mosquito predators, such as fish, water bugs and frogs, may play significant roles in biocontrol in the future [185].

As biocontrol agents, entomopathogenic fungi, bacteria and viruses have been developed to specifically kill mosquitoes. The most commonly used microorganism is Bti which destroys the gut of the mosquito larvae by producing $\delta$-endotoxin [186]. Several studies have indicated the lethal effect of entomopathogenic fungi, such as Metarhizium anisopliae, to adult mosquitoes [187]. The fungi sporulate to penetrate the cuticle of the mosquitoes, resulting in the death of mosquitoes by obliteration of tissues as well as the toxins produced [188].

Another method includes the release of genetically modified mosquitoes that have been infected with Wolbachia sp., an endosymbiotic bacteria [189] and of sterile-male mosquitoes [190]. The cytoplasmic incompatibility induced by Wolbachia sp. causes sterility, thereby suppressing mosquito populations. The presence of Wolbachia strain, wMelPop, reduces the adult lifespan via the inhibition of pathogen replication as well as the upregulation of immune genes [191, 192]. The sterile insect technique (SIT) can also be manipulated via genetically engineered sterile male mosquitoes, such as OX513A (which carries a repressible dominant lethal transgene insertion that causes lethality at the late larval or early pupal stages). These released sterile males subsequently mate with wild females, and the resultant offspring will die before adult metamorphosis which reduces their reproductive potential. Ultimately, field trials and further research on the sustainability and costeffectiveness of both approaches will be necessary.

In summary, the prevalence of dengue fever and increasing trend of resistance towards different categories of insecticides are alarming in many Southeast Asian countries. A well-researched understanding of the mechanism of resistance and susceptibility of the mosquitoes is of utmost importance for the development of an effective control method of Aedes mosquitoes in these endemic regions.

\footnotetext{
Abbreviations

AChE: Acetylcholinesterase; Bti: Bacillus thuringiensis israelensis; $\mathrm{CHC}$ : Cuticular hydrocarbon; CPR: NADPH-cytochrome $\mathrm{P} 450$ reductase; CYP: Cytochrome P450; DDT: Dichlorodiphenyltrichlorethane; F: Phenylalanine; GABA: $\gamma$-Aminobutyric acid; GST: Glutathione S-transferases; H: Histidine; $k d r$ : Knockdown resistance; L: Leucine; LLINs: Long-lasting insecticide nets; PBA1c: 3-Phenoxybenzyl alcohol; PBA1d: 3-Phenoxybenzaldehyde; PBAcid: 3-Phenoxybenzoic acid; RDL: Resistance to dieldrin gene; S: Serine; Vssc: Voltagesensitive sodium channel.
} 


\section{Supplementary Information}

The online version contains supplementary material available at https://doi. org/10.1186/s13071-021-04785-4.

Additional file 1: Table S1. Summary of characteristics data of the included studies.

\section{Acknowledgements}

This work was supported by fundamental research Grant scheme from Ministry of Education Malaysia (FRGS/1/2016/SKK11/IMU/02/1).

\section{Authors' contributions}

WSF developed the concept and the design of the manuscript. GSJ, LYQ, WST and MFH drafted the manuscript. MJW and RA provided key intellectual support and helped in revising the manuscript. All authors read and approved final manuscript.

\section{Funding}

The author(s) received support from Ministry of Education Malaysia under fundamental research Grant scheme (FRGS/1/2016/SKK11/IMU/02/1).

\section{Availability of data and materials}

Not applicable.

\section{Declarations}

Ethics approval and consent to participate

Not applicable.

\section{Consent for publication}

Not applicable.

\section{Competing interests}

The authors declare that they have no competing interests.

\section{Author details}

${ }^{1}$ International Medical University, 57000 Kuala Lumpur, Malaysia. ${ }^{2}$ Monash University Malaysia, 47500 Subang Jaya, Selangor, Malaysia. ${ }^{3}$ Institute for Research, Development and Innovation (IRDI), International Medical University, 57000 Kuala Lumpur, Malaysia. ${ }^{4}$ Institute for Medical Research, Jalan Pahang, 50588 Kuala Lumpur, Malaysia.

\section{Received: 28 October 2020 Accepted: 11 May 2021}

Published online: 10 June 2021

\section{References}

1. World Health Organization. Guidelines for dengue surveillance and mosquito control. 2nd ed. Manila: WHO Regional Office for the Western Pacific. 2003. https://apps.who.int/iris/bitstream/handle/10665/206987/ 9290610689 eng.pdf? sequence $=1 \&$ is Allowed $=y$. Accessed 28 0ct 2020

2. Brown JE, Evans BR, Zheng W, Obas V, Barrera-Martinez L, Egizi A, et al. Human impacts have shaped historical and recent evolution in Aedes aegypti, the dengue and yellow fever mosquito. Evolution. 2014;68:514-25. https://doi.org/10.1111/evo.12281.

3. Delatte H, Gimonneau G, Triboire A, Fontenille D. Influence of temperature on immature development, survival, longevity, fecundity, and gonotrophic cycles of Aedes albopictus, vector of chikungunya and dengue in the Indian Ocean. J Med Entomol. 2009;46:33-41. https:// doi.org/10.1603/033.046.0105.

4. Kraemer MU, Sinka ME, Duda KA, Mylne AQ, Shearer FM, Barker CM, et al. The global distribution of the arbovirus vectors Aedes aegypti and Ae. albopictus. Elife. 2015;4:e08347. https://doi.org/10.7554/eLife.08347.

5. Kraemer MU, Sinka ME, Duda KA, Mylne A, Shearer FM, Brady OJ, et al. The global compendium of Aedes aegypti and Ae. albopictus occurrence. Sci Data. 2015;2:150035. https://doi.org/10.1038/sdata.2015.35.
6. Raquin V, Lambrechts L. Dengue virus replicates and accumulates in Aedes aegypti salivary glands. Virology. 2017;507:75-81. https://doi.org/ 10.1016/j.virol.2017.04.009.

7. Ferreira-de-Lima VH, Lima-Camara TN. Natural vertical transmission of dengue virus in Aedes aegypti and Aedes albopictus: a systematic review. Parasites Vectors. 2018;11(1):77. https://doi.org/10.1186/ s13071-018-2643-9.

8. Moher D, Liberati A, Tetzlaff J, Altman DG. Preferred Reporting Items for Systematic reviews and Meta-Analyses: the PRISMA statement. BMJ. 2009;339:b2535. https://doi.org/10.1136/bmj.b2535.

9. Bhatt $\mathrm{S}$, Gething PW, Brady OJ, Messina JP, Farlow AW, Moyes CL, et al. The global distribution and burden of dengue. Nature. 2013;496:504-7. https://doi.org/10.1038/nature12060.

10. Huy R, Buchy P, Conan A, Ngan C, Ong S, Ali R, et al. National dengue surveillance in Cambodia 1980-2008: epidemiological and virological trends and the impact of vector control. Bull World Health Organ. 2010;88(9):650-7. https://doi.org/10.2471/BLT.09.073908.

11. Mia MS, Begum RA, Er AC, Abidin RD, Pereira JJ. Trends of dengue infections in Malaysia, 2000-2010. Asian Pac J Trop Med. 2013;6(6):462-6. https://doi.org/10.1016/S1995-7645(13)60075-9.

12. Struchiner CJ, Rocklov J, Wilder-Smith A, Massad E. Increasing dengue incidence in Singapore over the past 40 years: population growth, climate and mobility. PLoS ONE. 2015;10(8):e0136286. https://doi.org/ 10.1371/journal.pone.0136286.

13. Rajarethinam J, Ang LW, Ong J, Ycasas J, Hapuarachchi HC, Yap G, et al Dengue in Singapore from 2004 to 2016: Cyclical epidemic patterns dominated by serotypes 1 and 2. Am J Trop Med Hyg. 2018;99(1):20410. https://doi.org/10.4269/ajtmh.17-0819.

14. World Health Organization. Surveillance dengue. Situation reports. https://www.who.int/westernpacific/emergencies/surveillance/dengue. Accessed 11 Jan 2021.

15. World Health Organization. Dengue situation update number 610 . World Health Organisation Western Pacific Region; 2020. p. 1-5. https:// www.who.int/docs/default-source/wpro---documents/emergency/ surveillance/dengue/dengue-20201217.pdf?sfvrsn=fc80101d_45. Accessed 11 Jan 2021.

16. Republic of the Philippines Department of Health. Statistics: disease surveillance: Dengue. https://doh.gov.ph/statistics. Accessed 3 Feb 2021

17. National Disease Surveillance (Report 506) Thailand. http://www.boe moph.go.th/boedb/surdata/disease.php?dcontent $=$ old $\& d s=262766$. Accessed 3 Feb 2021.

18. The Republic of the Union of Myanmar Ministry of Health and Sports. https://mohs.gov.mm/cat/Annual\%20Public\%20Health\%20Statistics? pagenumber $=1$ \&pagesize $=40$. Accessed 3 Feb 2021.

19. Ministry of Health Singapore. Weekly Infectious Diseases Bulletin. https://www.moh.gov.sg/resources-statistics/infectious-disease-stati stics/2020/weekly-infectious-diseases-bulletin. Accessed 3 Feb 2021.

20. Ministry of Health Brunei Darussalam. Health information booklet 2004-2017. 2019. http://moh.gov.bn/SitePages/Health\%20Informat ion\%20Booklet.aspx. Accessed 18 Oct 2020.

21. Vineyard A. Spatial and temporal trends of dengue hemorrhagic fever in Mayanmar from 2004 to 2014. 2016. Master of Public Health thesis. http://d-scholarship.pitt.edu/27491/1/Vineyard_A_MPH_Essay_4_2016. doc. Accessed 18 Oct 2020.

22. National Environment Agency. Dengue cases. Singapore: Nationa Environment Agency. https://www.nea.gov.sg/dengue-zika/dengue/ dengue-cases. Accessed 3 Feb 2021

23. World Health Organization. Comprehensive guidelines for prevention and control of dengue and dengue haemorrhagic fever. Revised and expanded edition. (SEARO Technical Publication Series No. 60). Chapter 2: Disease burden of dengue fever and dengue hamorrhagic fever. 2011. https://apps.who.int/iris/bitstream/handle/10665/204894/B4751. pdf?sequence $=1$ \&isAllowed $=y$. Accessed 10 Jan 2021.

24. World Health Organization. Dengue and severe dengue. Database. https://www.who.int/health-topics/dengue-and-severe-dengue\#tab= tab_1. Accessed 3 Feb 2021

25. Arima Y, Edelstein ZR, Han HK, Matsui T. Epidemiologic update on the dengue situation in the Western Pacific Region, 2011. Western Pac Surveill Response J. 2013;4(2):47-54. https://doi.org/10.5365/WPSAR. 2012.3.4.019. 
26. UNITEDengue. UNited In Tackling Epidemic Dengue. UNITEDengue.org. https://www.unitedengue.org/regionaldengue.html. Accessed 31 Jan 2021

27. Arima Y, Chiew M, Matsui T, Emerging Disease Surveillance and Response Team, Division of Health Security and Emergencies, World Health Organization Regional Office for the Western Pacific. Epidemiological update on the dengue situation in the Western Pacific Region, 2012. Western Pac Surveill Response J. 2015;6(2):82-9. https://doi.org/ 10.5365/WPSAR.2014.5.4.002.

28. Khampapongpane B, Lewis HC, Ketmayoon P, Phonekeo D, Somoulay $\mathrm{V}$, Khamsing A, et al. National dengue surveillance in the Lao People's Democratic Republic, 2006-2012: epidemiological and laboratory findings. Western Pac Surveill Response J. 2014;5(1):7-13. https://doi.org/10. 5365/WPSAR.2014.5.1.001.

29. Ministry of Health Replubic of Indonesia. Health Profile Indonesia. https://www.kemkes.go.id/folder/view/01/structure-publikasi-pusda tin-profil-kesehatan.html. Accessed 3 Feb 2021

30. Chew $\mathrm{CH}$, Woon YL, Amin F, Adnan TH, Abdul Wahab AH, Ahmad $\mathrm{ZE}$, et al. Rural-urban comparisons of dengue seroprevalence in Malaysia. BMC Public Health. 2016;16:824. https://doi.org/10.1186/ s12889-016-3496-9.

31. Dhanoa A, Hassan SS, Jahan NK, Reidpath DD, Fatt QK, Ahmad MP, et al. Seroprevalence of dengue among healthy adults in a rural community in Southern Malaysia: a pilot study. Infect Dis Poverty. 2018;7:1. https:// doi.org/10.1186/s40249-017-0384-1.

32. Tan W, Liew JWK, Selvarajoo S, Lim XY, Foo CJ, Refai WF, et al. Inapparent dengue in a community living among dengue-positive Aedes mosquitoes and in a hospital in Klang Valley, Malaysia. Acta Trop. 2020;204:105330. https://doi.org/10.1016/j.actatropica.2020.105330

33. Duong V, Lambrechts L, Paul RE, Ly S, Lay RS, Long KC, et al. Asymptomatic humans transmit denque virus to mosquitoes. Proc Natl Acad Sci USA. 2015;112(47):14688-93. https://doi.org/10.1073/pnas.1508114112.

34. Ten Bosch QA, Clapham HE, Lambrechts L, Duong V, Buchy P, Althouse $\mathrm{BM}$, et al. Contributions from the silent majority dominate dengue virus transmission. PLoS Pathog. 2018;14(5):e1006965. https://doi.org/10. 1371/journal.ppat.1006965.

35. Koul O. Essential oils as green pesticides: potential and constraints. Biopesticides Int. 2008;4(1):63-84.

36. Gerba CP. Chapter 28-Environmental toxicology. In: Brusseau ML, Pepper IL, Gerba CP, editors. Environmental and pollution science. 3rd ed. London: Academic Press; 2019. p. 511-40.

37. Cuervo-Parra JA, Cortés TR, Ramirez-Lepe M. Chapter 7: Mosquito-borne diseases, pesticides used for mosquito control, and development of resistance to insecticides. In: Stanislav Trdan, ed. Insecticides resistance. 2016. https://doi.org/10.5772/61510.

38. Coats JR. Mechanisms of toxic action and structure-activity relationships for organochlorine and synthetic pyrethroid insecticides. Environ Health Perspect. 1990;87:255-62. https://doi.org/10.1289/ehp.9087255.

39. Aktar MW, Sengupta D, Chowdhury A. Impact of pesticides use in agriculture: their benefits and hazards. Interdiscip Toxicol. 2009;2(1):1-12. https://doi.org/10.2478/v10102-009-0001-7.

40. Loughney K, Kreber R, Ganetzky B. Molecular analysis of the para locus, a sodium channel gene in Drosophila. Cell. 1989;58(6):1143-54. https:// doi.org/10.1016/0092-8674(89)90512-6.

41. Catterall WA. Voltage-gated sodium channels at 60: structure, function and pathophysiology. J Physiol. 2012;590(11):2577-89. https://doi.org/ 10.1113/jphysiol.2011.224204.

42. Vijverberg HPM, van der Zalm JM, van den Bercken J. Similar mode of action of pyrethroids and DDT on sodium channel gating in myelinated nerves. Nature. 1982;295:601-3. https://doi.org/10.1038/295601a0.

43. Silver KS, Du Y, Nomura Y, Oliveira EE, Salgado VL, Zhorov BS, et al. Voltage-gated sodium channels as insecticide targets. Adv In Insect Phys. 2014;46:389-433. https://doi.org/10.1016/B978-0-12-417010-0. 00005-7.

44. Davies TG, Field LM, Usherwood PN, Williamson MS. DDT, pyrethrins, pyrethroids and insect sodium channels. IUBMB Life. 2007;59(3):151-62. https://doi.org/10.1080/15216540701352042.

45. Lawrence L, Casida JE. Stereospecific action of pyrethroid insecticides on the gamma-aminobutyric acid receptor-ionophore complex. Science. 1983;221(4618):1399-401. https://doi.org/10.1126/science.6310756.
46. Bloomquist JR Soderlund DM. Neurotoxic insecticides inhibit GABAdependent chloride uptake by mouse brain vesicles. Biochem Biophys Res Commun. 1985;133(1):37-43. https://doi.org/10.1016/0006291x(85)91838-8.

47. Namba T, Nolte CT, Jackrel J, Grob D. Poisoning due to organophosphate insecticides. Acute and chronic manifestations. Am J Med. 1971;50(4):475-92. https://doi.org/10.1016/0002-9343(71)90337-8.

48. Costa LG. Current issues in organophosphate toxicology. Clin Chim Acta. 2006:366(1-2):1-13. https://doi.org/10.1016/j.cca.2005.10.008.

49. Fukuto TR. Mechanism of action of organophosphorus and carbamate insecticides. Environ Health Perspect. 1990;87:245-54. https://doi.org/ 10.1289/ehp.9087245

50. Darvesh S, Darvesh KV, McDonald RS, Mataija D, Walsh R, Mothana S, et al. Carbamates with differential mechanism of inhibition toward acetylcholinesterase and butyrylcholinesterase. J Med Chem. 2008;51(14):4200-12. https://doi.org/10.1021/jm8002075.

51. Soderlund DM. Molecular mechanisms of pyrethroid insecticide neurotoxicity: recent advances. Arch Toxicol. 2012;86(2):165-81. https://doi. org/10.1007/s00204-011-0726-x.

52. Breckenridge CB, Holden L, Sturgess N, Weiner M, Sheets L, Sargent D, et al. Evidence for a separate mechanism of toxicity for the Type I and the Type II pyrethroid insecticides. Neurotoxicology. 2009;30(Suppl 1):S17-31. https://doi.org/10.1016/j.neuro.2009.09.002.

53. Gajendiran A, Abraham J. An overview of pyrethroid insecticides. Front Biol. 2018;13:79-90. https://doi.org/10.1007/s11515-018-1489-z.

54. Singh AK, Tiwari MN, Prakash O, Singh MP. A current review of cypermethrin-induced neurotoxicity and nigrostriatal dopaminergic neurodegeneration. Curr Neuropharmacol. 2012;10:64-71. https://doi. org/10.2174/157015912799362779.

55. Cao Z, Shafer TJ, Murray TF. Mechanisms of pyrethroid insecticideinduced stimulation of calcium influx in neocortical neurons. J Pharmacol Exp Ther. 2011;336(1):197-205. https://doi.org/10.1124/jpet.110. 171850.

56. Hemingway J, Hawkes NJ, McCarroll L, Ranson H. The molecular basis of insecticide resistance in mosquitoes. Insect Biochem Mol Biol. 2004;34(7):653-65. https://doi.org/10.1016/j.ibmb.2004.03.018.

57. Soderlund DM, Knipple DC. The molecular biology of knockdown resistance to pyrethroid insecticides. Insect Biochem Mol Biol. 2003;33(6):563-77. https://doi.org/10.1016/s0965-1748(03)00023-7.

58. Chang C. Inheritance and stability of sodium channel mutations associated with permethrin knockdown resistance in Aedes aegypti. Pestic Biochem Physiol. 2012;104(2):136-42. https://doi.org/10.1016/j.pestbp. 2012.06.003.

59. Xu Q, Liu H, Zhang L, Liu N. Resistance in the mosquito, Culex quinquefasciatus, and possible mechanisms for resistance. Pest Manag Sci. 2005;61(11):1096-102. https://doi.org/10.1002/ps.1090.

60. Moyes CL, Vontas J, Martins AJ, Ng LC, Koou SY, Dusfour I, et al. Contemporary status of insecticide resistance in the major Aedes vectors of arboviruses infecting humans. PLoS Negl Trop Dis. 2017;11(7):e0005625. https://doi.org/10.1371/journal.pntd.0005625.

61. Brengues C, Hawkes NJ, Chandre F, McCarroll L, Duchon S, Guillet P, et al. Pyrethroid and DDT cross-resistance in Aedes aegypti is correlated with novel mutations in the voltage-gated sodium channel gene. Med Vet Entomol. 2003;17(1):87-94. https://doi.org/10.1046/j.1365-2915. $2003.00412 x$

62. Du Y, Nomura Y, Zhorov BS, Dong K. Sodium channel mutations and pyrethroid resistance in Aedes aegypti. Insects. 2016;7(4):60. https://doi. org/10.3390/insects7040060.

63. Fernando SD, Hapugoda M, Perera R, Saavedra-Rodriguez K, Black WCt, De Silva NK. First report of V1016G and S989P knockdown resistant (kdr) mutations in pyrethroid-resistant Sri Lankan Aedes aegypti mosquitoes. Parasites Vectors. 2018;11:526. https://doi.org/10.1186/ s13071-018-3113-0.

64. Zhou X, Yang C, Liu N, Li M, Tong Y, Zeng X, et al . Knockdown resistance $(k d r)$ mutations within seventeen field populations of Aedes albopictus from Beijing China: first report of a novel V1016G mutation and evolutionary origins of kdr haplotypes. Parasit Vectors. 2019;12:180. https:// doi.org/10.1186/s13071-019-3423-x. 
65. Kushwah RB, Dykes CL, Kapoor N, AdakT, Singh OP. Pyrethroidresistance and presence of two knockdown resistance $(k d r)$ mutations, F1534C and a novel mutation T1520l, in Indian Aedes aegypti. PLoS Negl Trop Dis. 2015;9(1):e3332. https://doi.org/10.1371/journal.pntd.00033 32.

66. Ishak IH, Jaal Z, Ranson H, Wondji CS. Contrasting patterns of insecticide resistance and knockdown resistance (kdr) in the dengue vectors Aedes aegypti and Aedes albopictus from Malaysia. Parasites Vectors. 2015;8:181. https://doi.org/10.1186/s13071-015-0797-2.

67. Stenhouse SA, Plernsub S, Yanola J, Lumjuan N, Dantrakool A, Choochote W, et al. Detection of the V1016G mutation in the voltagegated sodium channel gene of Aedes aegypti (Diptera: Culicidae) by allele-specific PCR assay, and its distribution and effect on deltamethrin resistance in Thailand. Parasites Vectors. 2013;6(1):253. https://doi.org/ 10.1186/1756-3305-6-253

68. Du Y, Nomura Y, Satar G, Hu Z, Nauen R, He SY, et al. Molecular evidence for dual pyrethroid-receptor sites on a mosquito sodium channel. Proc Natl Acad Sci USA. 2013;110(29):11785-90. https://doi.org/10.1073/ pnas.1305118110

69. Smith LB, Kasai S, Scott JG. Pyrethroid resistance in Aedes aegypti and Aedes albopictus: important mosquito vectors of human diseases. Pestic Biochem Physiol. 2016;133:1-12. https://doi.org/10.1016/j.pestbp.2016. 03.005 .

70. Srisawat R, Komalamisra N, Eshita Y, Zheng M, Ono K, Itoh TQ, et al. Point mutations in domain II of the voltage-gated sodium channel gene in deltamethrin-resistant Aedes aegypti (Diptera: Culicidae). Appl Entomol Zool. 2010;45(2):275-82. https://doi.org/10.1303/aez.2010.275.

71. Pang SC, Chiang LP, Tan CH, Vythilingam I, Lam-Phua SG, Ng LC. Low efficacy of delthamethrin-treated net against Singapore Aedes aegypti is associated with kdr-type resistance. Trop Biomed. 2015;32(1):140-50.

72. Smith LB, Kasai S, Scott JG. Voltage-sensitive sodium channel mutations S989P + V1016G in Aedes aegypti confer variable resistance to pyrethroids, DDT and oxadiazines. Pest Manag Sci. 2018;74(3):737-45. https://doi.org/10.1002/ps.4771.

73. Prapanthadara L, Promtet N, Koottathep S, Somboon P, Suwonkerd W, McCarroll L, et al. Mechanisms of DDT and permethrin resistance in Aedes aegypti from Chiang Mai, Thailand. Dengue Bull. 2002;26:185-9. https://apps.who.int/iris/handle/10665/163771.

74. Saavedra-Rodriguez K, Urdaneta-Marquez L, Rajatileka S, Moulton M, Flores AE, Fernandez-Salas I, et al. A mutation in the voltage-gated sodium channel gene associated with pyrethroid resistance in Latin American Aedes aegypti. Insect Mol Biol. 2007;16(6):785-98. https://doi. org/10.1111/j.1365-2583.2007.00774.x.

75. Haddi K, Tome HWV, Du Y, Valbon WR, Nomura Y, Martins GF, et al. Detection of a new pyrethroid resistance mutation (V410L) in the sodium channel of Aedes aegypti: a potential challenge for mosquito control. Sci Rep. 2017;7:46549. https://doi.org/10.1038/srep46549.

76. Xu J, Bonizzoni M, Zhong D, Zhou G, Cai S, Li Y, et al. Multi-country survey revealed prevalent and novel F1534S mutation in voltage-gated sodium channel (VGSC) gene in Aedes albopictus. PLoS Negl Trop Dis. 2016;10(5):e0004696. https://doi.org/10.1371/journal.pntd.0004696.

77. Kasai S, Ng LC, Lam-Phua SG, Tang CS, Itokawa K, Komagata O, et al. First detection of a putative knockdown resistance gene in major mosquito vector, Aedes albopictus. Jpn J Infect Dis. 2011;64(3):217-21.

78. Chang C, Shen WK, Wang TT, Lin YH, Hsu EL, Dai SM. A novel amino acid substitution in a voltage-gated sodium channel is associated with knockdown resistance to permethrin in Aedes aegypti. Insect Biochem Mol Biol. 2009;39(4):272-8. https://doi.org/10.1016/j.ibmb.2009.01.001.

79. Maestre-Serrano R, Pareja-Loaiza P, Gomez Camargo D, Ponce-Garcia $\mathrm{G}$, Flores AE. Co-occurrence of V1016I and F1534C mutations in the voltage-gated sodium channel and resistance to pyrethroids in Aedes aegypti (L.) from the Colombian Caribbean region. Pest Manag Sci. 2019;75(6):1681-8. https://doi.org/10.1002/ps.5287.

80. Weill M, Lutfalla G, Mogensen K, Chandre F, Berthomieu A, Berticat C, et al. Comparative genomics: insecticide resistance in mosquito vectors. Nature. 2003;423(6936):136-7. https://doi.org/10.1038/423136b.

81. Weill M, Malcolm C, Chandre F, Mogensen K, Berthomieu A, Marquine $M$, et al. The unique mutation in ace-1 giving high insecticide resistance is easily detectable in mosquito vectors. Insect Mol Biol. 2004;13(1):1-7. https://doi.org/10.1111/j.1365-2583.2004.00452.x.
82. Alout H, Berthomieu A, Cui F, Tan Y, Berticat C, Qiao C, et al. Different amino-acid substitutions confer insecticide resistance through acetylcholinesterase 1 insensitivity in Culex vishnui and Culex tritaeniorhynchus (Diptera: Culicidae) from China. J Med Entomol. 2007;44(3):463-9. https://doi.org/10.1603/0022-2585(2007)44[463:dascir]2.0.co;2.

83. Alout H, Labbe P, Berthomieu A, Pasteur N, Weill M. Multiple duplications of the rare ace-1 mutation F290V in Culex pipiens natural populations. Insect Biochem Mol Biol. 2009;39(12):884-91. https://doi.org/10. 1016/j.ibmb.2009.10.005.

84. Alout $\mathrm{H}$, Weill M. Amino-acid substitutions in acetylcholinesterase 1 involved in insecticide resistance in mosquitoes. Chem Biol Interact. 2008;175(1-3):138-41. https://doi.org/10.1016/j.cbi.2008.03.018.

85. Bourne Y, Taylor P, Radic Z, Marchot P. Structural insights into ligand interactions at the acetylcholinesterase peripheral anionic site. EMBO J. 2003;22(1):1-12. https://doi.org/10.1093/emboj/cdg005.

86. Nabeshima T, Mori A, Kozaki T, Iwata Y, Hidoh O, Harada S, et al. An amino acid substitution attributable to insecticide-insensitivity of acetylcholinesterase in a Japanese encephalitis vector mosquito, Culex tritaeniorhynchus. Biochem Biophys Res Commun. 2004;313(3):794-801. https://doi.org/10.1016/j.bbrc.2003.11.141.

87. Ordentlich A, Barak D, Kronman C, Flashner Y, Leitner M, Segall Y, et al. Dissection of the human acetylcholinesterase active center determinants of substrate specificity. Identification of residues constituting the anionic site, the hydrophobic site, and the acyl pocket. J Biol Chem. 1993;268(23):17083-95.

88. Taylor-Wells J, Brooke BD, Bermudez I, Jones AK. The neonicotinoid imidacloprid, and the pyrethroid deltamethrin, are antagonists of the insect Rdl GABA receptor. J Neurochem. 2015;135(4):705-13. https:// doi.org/10.1111/jnc.13290.

89. Nys M, Kesters D, Ulens C. Structural insights into Cys-loop receptor function and ligand recognition. Biochem Pharmacol. 2013:86(8):104253. https://doi.org/10.1016/j.bcp.2013.07.001.

90. Raymond-Delpech V, Matsuda K, Sattelle BM, Rauh JJ, Sattelle DB. Ion channels: molecular targets of neuroactive insecticides. Invert Neurosci. 2005;5(3-4):119-33. https://doi.org/10.1007/s10158-005-0004-9.

91. Hoopengardner B, Bhalla T, Staber C, Reenan R. Nervous system targets of RNA editing identified by comparative genomics. Science. 2003;301(5634):832-6. https://doi.org/10.1126/science.1086763.

92. Taylor-Wells J, Senan A, Bermudez I, Jones AK. Species specific RNA A-to-l editing of mosquito RDL modulates GABA potency and influences agonistic, potentiating and antagonistic actions of ivermectin. Insect Biochem Mol Biol. 2018;93:1-11. https://doi.org/10.1016/j.ibmb. 2017.12.001.

93. Tantely ML, Tortosa P, Alout H, Berticat C, Berthomieu A, Rutee A, et al. Insecticide resistance in Culex pipiens quinquefasciatus and Aedes albopictus mosquitoes from La Reunion Island. Insect Biochem Mol Biol. 2010;40(4):317-24. https://doi.org/10.1016/j.ibmb.2010.02.005.

94. Hemingway J, Ranson $\mathrm{H}$. Insecticide resistance in insect vectors of human disease. Annu Rev Entomol. 2000;45:371-91. https://doi.org/10. 1146/annurev.ento.45.1.371.

95. Liu N. Insecticide resistance in mosquitoes: impact, mechanisms, and research directions. Annu Rev Entomol. 2015;60:537-59. https://doi. org/10.1146/annurev-ento-010814-020828.

96. Murataliev MB, Guzov VM, Walker FA, Feyereisen R. P450 reductase and cytochrome b5 interactions with cytochrome P450: effects on house fly CYP6A1 catalysis. Insect Biochem Mol Biol. 2008;38(11):1008-15. https://doi.org/10.1016/j.ibmb.2008.08.007.

97. Scott JG. Cytochromes P450 and insecticide resistance. Insect Biochem Mol Biol. 1999;29(9):757-77. https://doi.org/10.1016/s0965-1748(99) 00038-7.

98. Smith LB, Tyagi R, Kasai S, Scott JG. CYP-mediated permethrin resistance in Aedes aegypti and evidence for trans-regulation. PLoS Negl Trop Dis. 2018;12(11):e0006933. https://doi.org/10.1371/journal.pntd.0006933.

99. Poupardin R, Srisukontarat W, Yunta C, Ranson H. Identification of carboxylesterase genes implicated in temephos resistance in the dengue vector Aedes aegypti. PLoS Negl Trop Dis. 2014;8(3):e2743. https://doi. org/10.1371/journal.pntd.0002743.

100. Strode C, Wondji CS, David JP, Hawkes NJ, Lumjuan N, Nelson DR, et al. Genomic analysis of detoxification genes in the mosquito Aedes aegypti. 
Insect Biochem Mol Biol. 2008;38(1):113-23. https://doi.org/10.1016/j. ibmb.2007.09.007.

101. Poupardin R, Riaz MA, Jones CM, Chandor-Proust A, Reynaud S, David JP. Do pollutants affect insecticide-driven gene selection in mosquitoes? Experimental evidence from transcriptomics. Aquat Toxicol. 2012;114115:49-57. https://doi.org/10.1016/j.aquatox.2012.02.001.

102. Marcombe S, Poupardin R, Darriet F, Reynaud S, Bonnet J, Strode C, et al. Exploring the molecular basis of insecticide resistance in the dengue vector Aedes aegypti: a case study in Martinique Island (French West Indies). BMC Genomics. 2009;10:494. https://doi.org/10.1186/ 1471-2164-10-494.

103. Marcombe S, Mathieu RB, Pocquet N, Riaz MA, Poupardin R, Selior S, et al. Insecticide resistance in the dengue vector Aedes aegypti from Martinique: distribution, mechanisms and relations with environmental factors. PLoS ONE. 2012;7(2):e30989. https://doi.org/10.1371/journal. pone.0030989.

104. Strode C, de Melo-Santos M, Magalhaes T, Araujo A, Ayres C. Expression profile of genes during resistance reversal in a temephos selected strain of the dengue vector, Aedes aegypti. PLoS ONE. 2012;7(8):e39439. https://doi.org/10.1371/journal.pone.0039439.

105. Chandor-Proust A, Bibby J, Regent-Kloeckner M, Roux J, Guittard-Crilat E, Poupardin R, et al. The central role of mosquito cytochrome P450 CYP6Zs in insecticide detoxification revealed by functional expression and structural modelling. Biochem J. 2013:455(1):75-85. https://doi.org/ 10.1042/BJ20130577.

106. Stevenson BJ, Pignatelli P, Nikou D, Paine MJ. Pinpointing P450s associated with pyrethroid metabolism in the dengue vector, Aedes aegypti: developing new tools to combat insecticide resistance. PLoS Negl Trop Dis. 2012;6(3):e1595. https://doi.org/10.1371/journal.pntd.0001595.

107. Ishak IH, Riveron JM, Ibrahim SS, Stott R, Longbottom J, Irving H, et al. The cytochrome P450 gene CYP6P12 confers pyrethroid resistance in kdr-free Malaysian populations of the dengue vector Aedes albopictus. Sci Rep. 2016;6:24707. https://doi.org/10.1038/srep24707.

108. Takaku T, Mikata K, Matsui M, Nishioka K, Isobe N, Kaneko H. In vitro metabolism of trans-permethrin and its major metabolites, PBalc and PBacid, in humans. J Agric Food Chem. 2011;59(9):5001-5. https://doi. org/10.1021/jf200032q.

109. Nakamura Y, Sugihara K, Sone T, Isobe M, Ohta S, Kitamura S. The in vitro metabolism of a pyrethroid insecticide, permethrin, and its hydrolysis products in rats. Toxicology. 2007;235(3):176-84. https://doi.org/10. 1016/j.tox.2007.03.016.

110. Karunaratne SH, Hemingway J, Jayawardena KG, Dassanayaka V Vaughan A. Kinetic and molecular differences in the amplified and non-amplified esterases from insecticide-resistant and susceptible Culex quinquefasciatus mosquitoes. J Biol Chem. 1995;270(52):31124-8. https://doi.org/10.1074/jbc.270.52.31124.

111. Vaughan A, Hemingway J. Mosquito carboxylesterase Esta21 (A2): cloning and sequence of the full-length CDNA for a major insecticide resistance gene worldwide in the mosquito Culex quinquefasciatus. J Biol Chem. 1995;270:17044-9. https://doi.org/10.1074/jbc.270.28.17044.

112. Hemingway J. The molecular basis of two contrasting metabolic mechanisms of insecticide resistance. Insect Biochem Mol Biol. 2000:30(11):1009-15. https://doi.org/10.1016/s0965-1748(00)00079-5.

113. Poirie M, Raymond M, Pasteur N. Identification of two distinct amplifications of the esterase B locus in Culex pipiens (L.) mosquitoes from Mediterranean countries. Biochem Genet. 1992;30:13-26. https://doi. org/10.1007/BF00554424.

114. Farnsworth C, Teese M, Yuan G, Li YQ, Scott C, Zhang X, et al. Esterasebased metabolic resistance to insecticides in heliothine and spodopteran pests. J Pestic Sci. 2010;35:275-89. https://doi.org/10.1584/JPEST ICS.R10-13.

115. Sogorb MA, Vilanova E. Enzymes involved in the detoxification of organophosphorus, carbamate and pyrethroid insecticides through hydrolysis. Toxicol Lett. 2002;128(1-3):215-28. https://doi.org/10.1016/ s0378-4274(01)00543-4.

116. Paton MG, Karunaratne SH, Giakoumaki E, Roberts N, Hemingway J. Quantitative analysis of gene amplification in insecticide-resistant Culex mosquitoes. Biochem J. 2000;346(Pt 1):17-24.

117. Mourya DT, Hemingway J, Leake CJ. Changes in enzyme titres with age in four geographical strains of Aedes aegypti and their association with insecticide resistance. Med Vet Entomol. 1993;7(1):11-6. https://doi.org/ 10.1111/j.1365-2915.1993.tb00645.x.

118. Che-Mendoza A, Penilla Navarro R, Rodríguez D. Insecticide resistance and glutathione S-transferases in mosquitoes: a review. Afr J Biotechnol. 2008:8(8):1386-97.

119. Ladner JE, Parsons JF, Rife CL, Gilliland GL, Armstrong RN. Parallel evolutionary pathways for glutathione transferases: structure and mechanism of the mitochondrial class kappa enzyme rGSTK1-1. Biochemistry. 2004:43(2):352-61. https://doi.org/10.1021/bi035832z.

120. Morel F, Rauch C, Petit E, Piton A, Theret N, Coles B, et al. Gene and protein characterisation of the human glutathione $\mathrm{S}$-transferase kappa and evidence for a peroxisomal localisation. J Biol Chem. 2004;79(16):16246-53. https://doi.org/10.1074/jbc.M313357200.

121. Lumjuan N, Stevenson BJ, Prapanthadara LA, Somboon P, Brophy PM, Loftus BJ, et al. The Aedes aegypti glutathione transferase family. Insect Biochem Mol Biol. 2007;37(10):1026-35. https://doi.org/10.1016/j.ibmb. 2007.05.018.

122. Pavlidi N, Vontas J, Van Leeuwen T. The role of glutathione S-transferases (GSTs) in insecticide resistance in crop pests and disease vectors. Curr Opin Insect Sci. 2018;27:97-102. https://doi.org/10.1016/j.cois.2018.04. 007.

123. Mannervik B. The isoenzymes of glutathione transferase. Adv Enzymol Relat Areas Mol Biol. 1985;57:357-417. https://doi.org/10.1002/97804 70123034.ch5.

124. Clark AG, Shamaan NA. Evidence that DDT-dehydrochlorinase from the house fly is a glutathione S-transferase. Pestic Biochem Physiol. 1984;22(3):249-61. https://doi.org/10.1016/0048-3575(84)90018-X.

125. Grant DF, Dietze EC, Hammock BD. Glutathione S-transferase isozymes in Aedes aegypti: purification, characterisation, and isozyme-specific regulation. Insect Biochem. 1991;21:421-33. https://doi.org/10.1016/ 0020-1790(91)90009-4.

126. Lumjuan N, MaCarroll L, Prapanthadara LA, Hemingway J, Ranson H. Elevated activity of an Epsilon class glutathione S-transferase confers DDT resistance in the dengue vector, Aedes aegypti. Insect Biochem Mol Biol. 2005;35(8):861-71. https://doi.org/10.1016/j.ibmb.2005.03.008.

127. Nkya TE, Akhouayri I, Kisinza W, David JP. Impact of environment on mosquito response to pyrethroid insecticides: facts, evidences and prospects. Insect Biochem Mol Biol. 2013;43(4):407-16. https://doi.org/ 10.1016/j.ibmb.2012.10.006.

128. Kasai S, Komagata O, Itokawa K, Shono T, Ng LC, Kobayashi M, et al. Mechanisms of pyrethroid resistance in the dengue mosquito vector, Aedes aegypti: target site insensitivity, penetration, and metabolism. PLoS Negl Trop Dis. 2014;8(6):e2948. https://doi.org/10.1371/journal. pntd.0002948.

129. Bass C, Jones CM. Mosquitoes boost body armor to resist insecticide attack. Proc Natl Acad Sci USA. 2016;113(33):9145-7. https://doi.org/10. 1073/pnas.1610992113.

130. Carrasco D, Lefevre T, Moiroux N, Pennetier C, Chandre F, Cohuet A. Behavioural adaptations of mosquito vectors to insecticide control. Curr Opin Insect Sci. 2019;34:48-54. https://doi.org/10.1016/j.cois.2019.03. 005.

131. Grieco JP, Achee NL, Sardelis MR, Chauhan KR, Roberts DR. A novel high-throughput screening system to evaluate the behavioral response of adult mosquitoes to chemicals. J Am Mosq Control Assoc. 2005;21(4):404-11. https://doi.org/10.2987/8756-971X(2006)21[404: ANHSST]2.0.CO;2.

132. Cutler GC. Insects, insecticides and hormesis: evidence and considerations for study. Dose Response. 2013;11(2):154-77. https://doi.org/10. 2203/dose-response.12-008.Cutler.

133. Boyer S, Lopes S, Prasetyo D, Hustedt J, Sarady AS, Doum D, et al. Resistance of Aedes aegypti (Diptera: Culicidae) populations to deltamethrin, permethrin, and temephos in Cambodia. Asia Pac J Public Health 2018;30(2):158-66. https://doi.org/10.1177/1010539517753876.

134. Shepard DS, Undurraga EA, Halasa YA. Economic and disease burden of dengue in Southeast Asia. PLoS NegI Trop Dis. 2013;7(2):e2055. https:// doi.org/10.1371/journal.pntd.0002055.

135. Polson KA, Curtis C, Seng CM, Olson JG, Chantha N, Rawlins SC. Susceptibility of two Cambodian populations of Aedes aegypti mosquito larvae to temephos during 2001. Dengue Bull. 2001;25:79-84. https://apps. who.int/iris/handle/10665/163688. 
136. Yanola J, Somboon P, Walton C, Nachaiwieng W, Somwang P, Prapanthadara LA. High-throughput assays for detection of the F1534C mutation in the voltage-gated sodium channel gene in permethrinresistant Aedes aegypti and the distribution of this mutation throughout Thailand. Trop Med Int Health. 2011;16(4):501-9. https://doi.org/10. 1111/j.1365-3156.2011.02725.x.

137. Saingamsook J, Saeung A, Yanola J, Lumjuan N, Walton C, Somboon P. A multiplex PCR for detection of knockdown resistance mutations, V1016G and F1534C, in pyrethroid-resistant Aedes aegypti. Parasites Vectors. 2017;10:465. https://doi.org/10.1186/s13071-017-2416-x.

138. Haziqah-Rashid A, Chen CD, Lau KW, Low VL, Sofian-Azirun M, Suana IW, et al. Monitoring insecticide resistance profiles of Aedes aegypti (Diptera: Culicidae) in the Sunda Islands of Indonesia based on diagnostic doses of larvicides. J Med Entomol. 2019;56(2):514-8. https://doi.org/10.1093/ jme/tjy208.

139. Mulyatno KC, Yamanaka A, Ngadino, Konishi E. Resistance of Aedes aegypti (L.) larvae to temephos in Surabaya, Indonesia. Southeast Asian J Trop Med Public Health. 2012;43(1):29-33.

140. Wuliandari JR, Lee SF, White VL, Tantowijoyo W, Hoffmann AA, EndersbyHarshman NM. Association between three mutations, F1565C, V1023G and S996P, in the voltage-sensitive sodium channel gene and knockdown resistance in Aedes aegypti from Yogyakarta, Indonesia. Insects. 2015;6(3):658-85. https://doi.org/10.3390/insects6030658.

141. Hamid PH, Prastowo J, Widyasari A, Taubert A, Hermosilla C. Knockdown resistance $(k d r)$ of the voltage-gated sodium channel gene of Aedes aegypti population in Denpasar, Bali, Indonesia. Parasites Vectors. 2017;10(1):283. https://doi.org/10.1186/s13071-017-2215-4.

142. Sayono S, Hidayati AP, Fahri S, Sumanto D, Dharmana E, Hadisaputro $\mathrm{S}$, et al. Distribution of voltage-gated sodium channel (Nav) alleles among the Aedes aegypti populations in Central Java province and its association with resistance to pyrethroid insecticides. PLOS ONE. 2016;11(3):e0150577. https://doi.org/10.1371/journal.pone.0150577.

143. Hamid PH, Prastowo J, Ghiffari A, Taubert A, Hermosilla C. Aedes aegypti resistance development to commonly used insecticides in Jakarta, Indonesia. PLoS ONE. 2017;12(12):e0189680. https://doi.org/10.1371/ journal.pone. 0189680

144. Hamid PH, Ninditya VI, Ghiffari A, Taubert A, Hermosilla C. The V1016G mutation of the voltage-gated sodium channel (VGSC) gene contributes to the insecticide resistance of Aedes aegypti from Makassar Indonesia. Parasitol Res. 2020;119:2075-83. https://doi.org/10.1007/ s00436-020-06720-5.

145. Hasmiwati, Rusjdi S, Nofita E. Detection of Ace-1 gene with insecticides resistance in Aedes aegypti populations from DHF-endemic areas in Padang, Indonesia. Biodiversitas. 2018;19(1):31-6. https://doi.org/10. 13057/biodiv/d190105.

146. Putra R, Ahmad I, Prasetyo D, Susanti S, Rahayu R, Hariani N. Detection of insecticide resistance in the larvae of some Aedes aegypti (Diptera: Culicidae) strains from Java, Indonesia to temephos, malathion and permethrin. Int J Mosquito Res. 2016:3:23-8.

147. Amelia-Yap ZH, Sofian-Azirun M, Chen CD, Lau KW, Suana IW, Syahputra E, et al. V1016G point mutation: the key mutation in the voltage-gated sodium channel (VGSC) gene of pyrethroid-resistant Aedes aegypti (Diptera: Culicidae) in Indonesia. J Med Entomol. 2019;56(4):953-8. https:// doi.org/10.1093/jme/tjz035.

148. Amelia-Yap ZH, Chen CD, Sofian-Azirun M, Lau KW, Suana IW, Harmonis, et al. Efficacy of mosquito coils: cross-resistance to pyrethroids in Aedes aegypti (Diptera: Culicidae) from Indonesia. J Econ Entomol. 2018;111(6):2854-60. https://doi.org/10.1093/jee/toy296.

149. Tangena JA, Marcombe S, Thammavong P, Chonephetsarath S, Somphong B, Sayteng K, et al. Bionomics and insecticide resistance of the arboviral vector Aedes albopictus in northern Lao PDR. PLOS ONE. 2018;13(10):e0206387. https://doi.org/10.1371/journal.pone.0206387.

150. Marcombe S, Fustec B, Cattel J, Chonephetsarath S, Thammavong P, Phommavanh N, et al. Distribution of insecticide resistance and mechanisms involved in the arbovirus vector Aedes aegypti in Laos and implication for vector control. PLoS Negl Trop Dis. 2019;13(12):e0007852. https://doi.org/10.1371/journal.pntd.0007852.

151. Marcombe S, Chonephetsarath S, Thammavong P, Brey PT. Alternative insecticides for larval control of the dengue vector Aedes aegypti in Lao PDR: insecticide resistance and semi-field trial study. Parasites Vectors. 2018;11:616. https://doi.org/10.1186/s13071-018-3187-8.
152. Rasli R, Lee HL, Nazni WA, Hamid N, Ali R, Asuad M, et al. Pyrethroid resistance status of Aedes (Stegomyia) aegypti (Linneaus) from dengue endemic areas in Peninsular Malaysia. Int Med J Malays. 2017;16(2):73-8.

153. Rasli R, Lee HL, Wasi Ahmad N, Fikri SFF, Ali R, Muhamed KA, et al. Susceptibility status and resistance mechanisms in permethrin-selected, laboratory susceptible and field-collected Aedes aegypti from Malaysia. Insects. 2018;9(2):43. https://doi.org/10.3390/insects9020043.

154. Leong CS, Vythilingam I, Wong ML, Wan Sulaiman WY, Lau YL. Aedes aegypti (Linnaeus) larvae from dengue outbreak areas in Selangor showing resistance to pyrethroids but susceptible to organophosphates. Acta Trop. 2018;185:115-26. https://doi.org/10.1016/j.actat ropica.2018.05.008.

155. Abu Hasan H, Jaal Z, Ranson H, McCall P. Pyrethroid and organophosphate susceptibility status of Aedes aegypti (Linnaeus) and Aedes albopictus (Skuse) in Penang, Malaysia. Int J Entomol Res. 2015;03(03):91-5.

156. Leong CS, Vythilingam I, Liew JW, Wong ML, Wan-Yusoff WS, Lau YL. Enzymatic and molecular characterisation of insecticide resistance mechanisms in field populations of Aedes aegypti from Selangor, Malaysia. Parasites Vectors. 2019;12:236. https://doi.org/10.1186/ s13071-019-3472-1.

157. Ishak IH, Kamgang B, Ibrahim SS, Riveron JM, Irving H, Wondji CS. Pyrethroid resistance in Malaysian populations of dengue vector Aedes aegypti is mediated by CYP9 family of cytochrome P450 genes. PLoS Negl Trop Dis. 2017;1 1(1):e0005302. https://doi.org/10.1371/journal. pntd.0005302.

158. Elia-Amira NMR, Chen CD, Lau KW, Lee HL, Low VL, Norma-Rashid Y, et al. Organophosphate and organochlorine resistance in larval stage of Aedes albopictus (Diptera: Culicidae) in Sabah, Malaysia. J Econ Entomol. 2018;111(5):2488-92. https://doi.org/10.1093/jee/toy184.

159. Elia-Amira NMR, Chen CD, Low VL, Lau KW, Haziqah-Rashid A, AmeliaYap ZH, et al. Adulticide resistance status of Aedes albopictus (Diptera: Culicidae) in Sabah, Malaysia: a statewide assessment. J Med Entomol. 2019;56(6):1715-25. https://doi.org/10.1093/jme/tjz117.

160. Kawada H, Oo SZ, Thaung S, Kawashima E, Maung YN, Thu HM, et al. Cooccurrence of point mutations in the voltage-gated sodium channel of pyrethroid-resistant Aedes aegypti populations in Myanmar. PLoS Negl Trop Dis. 2014;8(7):e3032. https://doi.org/10.1371/journal.pntd.00030 32.

161. Oo TT, Storch V, Madon MB, Becker N. Factors influencing the seasonal abundance of Aedes (Stegomyia) aegypti and the control strategy of dengue and dengue haemorrhagic fever in Thanlyin Township, Yangon City, Myanmar. Trop Biomed. 2011;28(2):302-11.

162. World Health Organization. Management of insecticide resistance among vectors of public health importance. In: Report of the ninth meeting of the Global Collaboration for Development of Pesticides for Public Health. Geneva: World Health Organisation. 2014.

163. Lee RM, Choong CT, Goh BP, Ng LC, Lam-Phua SG. Bioassay and biochemical studies of the status of pirimiphos-methyl and cypermethrin resistance in Aedes (Stegomyia) aegypti and Aedes (Stegomyia) albopictus (Diptera: Culicidae) in Singapore. Trop Biomed. 2014;31 (4):670-9.

164. Koou SY, Chong CS, Vythilingam I, Ng LC, Lee CY. Pyrethroid resistance in Aedes aegypti larvae (Diptera: Culicidae) from Singapore. J Med Entomol. 2014:51(1):170-81. https://doi.org/10.1603/me13113.

165. Koou SY, Chong CS, Vythilingam I, Lee CY, Ng LC. Insecticide resistance and its underlying mechanisms in field populations of Aedes aegypti adults (Diptera: Culicidae) in Singapore. Parasites Vectors. 2014;7:471. https://doi.org/10.1186/s13071-014-0471-0.

166. Hirata K, Komagata O, Itokawa K, Yamamoto A, Tomita T, Kasai S. A single crossing-over event in voltage-sensitive $\mathrm{Na}^{+}$channel genes may cause critical failure of dengue mosquito control by insecticides. PLoS Negl Trop Dis. 2014;8(8):e3085. https://doi.org/10.1371/journal.pntd. 0003085.

167. Kasai S, Caputo B, Tsunoda T, Cuong TC, Maekawa Y, Lam-Phua SG, et al. First detection of a Vssc allele V1016G conferring a high level of insecticide resistance in Aedes albopictus collected from Europe (Italy) and Asia (Vietnam), 2016: a new emerging threat to controlling arboviral diseases. Euro Surveill. 2019;24(5):1700847. https://doi.org/10.2807/ 1560-7917.ES.2019.24.5.1700847.

168. Somboon P, Prapanthadara LA, Suwonkerd W. Insecticide susceptibility tests of Anopheles minimus s.l., Aedes aegypti, Aedes albopictus, and 
Culex quinquefasciatus in northern Thailand. Southeast Asian J Trop Med Public Health. 2003;34(1):87-93.

169. Jirakanjanakit N, Rongnoparut P, Saengtharatip S, Chareonviriyaphap T, Duchon S, Bellec C, et al. Insecticide susceptible/resistance status in Aedes (Stegomyia) aegypti and Aedes (Stegomyia) albopictus (Diptera: Culicidae) in Thailand during 2003-2005. J Econ Entomol. 2007;100(2):545-50. https://doi.org/10.1603/0022-0493(2007)100[545: irsias]2.0.co;2.

170. Thongwat D, Bunchu N. Susceptibility to temephos, permethrin and deltamethrin of Aedes aegypti (Diptera: Culicidae) from Muang district, Phitsanulok Province, Thailand. Asian Pac J Trop Med. 2015;8(1):14-8. https://doi.org/10.1016/S1995-7645(14)60180-2.

171. Plernsub S, Saingamsook J, Yanola J, Lumjuan N, Tippawangkosol P, Sukontason K, et al. Additive effect of knockdown resistance mutations, S989P, V1016G and F1534C, in a heterozygous genotype conferring pyrethroid resistance in Aedes aegypti in Thailand. Parasit Vectors. 2016;9(1):417. https://doi.org/10.1186/s13071-016-1713-0.

172. Yanola J, Somboon P, Walton C, Nachaiwieng W, Prapanthadara L. A novel F1552/C1552 point mutation in the Aedes aegypti voltage-gated sodium channel gene associated with permethrin resistance. Pestic Biochem Physiol. 2010;96(3):127-31. https://doi.org/10.1016/j.pestbp. 2009.10.005.

173. Faucon F, Dusfour I, Gaude T, Navratil V, Boyer F, Chandre F, et al. Identifying genomic changes associated with insecticide resistance in the dengue mosquito Aedes aegypti by deep targeted sequencing. Genome Res. 2015;25(9):1347-59. https://doi.org/10.1101/gr.189225. 115.

174. Pimsamarn S, Sornpeng W, Akksilp S, Paeporn P, Limpawitthayakul M. Detection of insecticide resistance in Aedes aegypti to organophosphate and synthetic pyrethroid compounds in the north-east of Thailand. Dengue Bull. 2009;33:194-202. https://apps.who.int/iris/handle/ 10665/170964.

175. Thanispong K, Sathantriphop S, Malaithong N, Bangs MJ, Chareonviriyaphap T. Establishment of diagnostic doses of five pyrethroids for monitoring physiological resistance in Aedes albopictus in Thailand. $J$ Am Mosq Control Assoc. 2015;31(4):346-52. https://doi.org/10.2987/ moco-31-04-346-352.1.

176. Frances SP, Morton CJ, Pettit WJ. Studies of the susceptibility of Aedes aegypti (Diptera: Culicidae) from Timor-Leste to pyrethroid and organophosphate insecticides. Austral Entomol. 2016;55(3):303-7. https://doi. org/10.1111/aen.12186.

177. Huong VD, Thi Bach Ngoc N. Susceptibility of Aedes aegypti to insecticides in South Vietnam. Dengue Bull. 1999;23:85-88. https://apps.who. int/iris/handle/10665/148663.

178. Thi KP, Viet HH, Nguyen HM. Major resistant mechanism to insecticides of Aedes aegypti mosquito: a vector of dengue and Zika virus in Vietnam. SM Trop Med J. 2016;1 (2):1010. https://doi.org/10.36876/smtmj. 1010.

179. Nguyen D. Mapping insecticide resistance in dengue vectors in Northern Vietnam, 2010-2013. Vector Biol J. 2016;1 (1):1-6. https://doi.org/10. 4172/2473-4810.1000105.

180. Kawada H, Higa Y, Komagata O, Kasai S, Tomita T, Thi Yen N, et al. Widespread distribution of a newly found point mutation in voltage-gated sodium channel in pyrethroid-resistant Aedes aegypti populations in
Vietnam. PLoS Negl Trop Dis. 2009;3(10):e527. https://doi.org/10.1371/ journal.pntd.0000527.

181. Soumare MK, Cilek JE. The effectiveness of Mesocyclops longisetus (Copepoda) for the control of container-inhabiting mosquitoes in residential environments. J Am Mosq Control Assoc. 2011;27(4):376-83. https://doi.org/10.2987/11-6129.1.

182. Mahesh Kumar P, Murugan K, Kovendan K, Panneerselvam C, Prasanna Kumar K, Amerasan D, et al. Mosquitocidal activity of Solanum xanthocarpum fruit extract and copepod Mesocyclops thermocyclopoides for the control of dengue vector Aedes aegypti. Parasitol Res. 2012;111(2):609-18. https://doi.org/10.1007/s00436-012-2876-z.

183. Kay BH, Tuyet Hanh TT, Le NH, Quy TM, Nam VS, Hang PV, et al. Sustainability and cost of a community-based strategy against Aedes aegypti in northern and central Vietnam. Am J Trop Med Hyg. 2010;82(5):822-30. https://doi.org/10.4269/ajtmh.2010.09-0503.

184. Nam VS, Yen NT, Duc HM, Tu TC, Thang VT, Le NH, et al. Communitybased control of Aedes aegypti by using Mesocyclops in southern Vietnam. Am J Trop Med Hyg. 2012;86(5):850-9. https://doi.org/10. 4269/ajtmh.2012.11-0466.

185. Murugan K, Priyanka V, Dinesh D, Madhiyazhagan P, Panneerselvam C, Subramaniam J, et al. Predation by Asian bullfrog tadpoles, Hoplobatrachus tigerinus, against the dengue vector, Aedes aegypti, in an aquatic environment treated with mosquitocidal nanoparticles. Parasitol Res. 2015;114(10):3601-10. https://doi.org/10.1007/s00436-015-4582-0.

186. Melo AL, Soccol VT, Soccol CR. Bacillus thuringiensis: mechanism of action, resistance, and new applications: a review. Crit Rev Biotechnol. 2016;36(2):317-26. https://doi.org/10.3109/07388551.2014.960793.

187. Paula AR, Carolino AT, Paula CO, Samuels R. The combination of the entomopathogenic fungus Metarhizium anisopliae with the insecticide Imidacloprid increases virulence against the dengue vector Aedes aegypti (Diptera: Culicidae). Parasites Vectors. 2011;4:8. https://doi.org/ 10.1186/1756-3305-4-8

188. Scholte EJ, Knols BG, Samson RA, Takken W. Entomopathogenic fungi for mosquito control: a review. J Insect Sci. 2004;4:19. https://doi.org/10. 1093/jis/4.1.19.

189. Guruprasad N, Jalali S, Hp P. Wolbachia - a foe for mosquitoes. Asian Pac JTrop Dis. 2014;4(1):78-81. https://doi.org/10.1016/S2222-1808(14) 60319-4.

190. Lacroix R, McKemey AR, Raduan N, Kwee Wee L, Hong Ming W, Guat Ney T, et al. Open field release of genetically engineered sterile male Aedes aegypti in Malaysia. PLoS ONE. 2012;7(8):e42771. https://doi.org/ 10.1371/journal.pone.0042771.

191. Moreira LA, Iturbe-Ormaetxe I, Jeffery JA, Lu G, Pyke AT, Hedges LM, et al. A Wolbachia symbiont in Aedes aegypti limits infection with dengue, Chikungunya, and Plasmodium. Cell. 2009;139(7):1268-78. https:// doi.org/10.1016/j.cell.2009.11.042.

192. Bian G, Xu Y, Lu P, Xie Y, Xi Z. The endosymbiotic bacterium Wolbachia induces resistance to dengue virus in Aedes aegypti. PLoS Pathog. 2010;6(4):e1000833. https://doi.org/10.1371/journal.ppat.1000833.

\section{Publisher's Note}

Springer Nature remains neutral with regard to jurisdictional claims in published maps and institutional affiliations.
Ready to submit your research? Choose BMC and benefit from:

- fast, convenient online submission

- thorough peer review by experienced researchers in your field

- rapid publication on acceptance

- support for research data, including large and complex data types

- gold Open Access which fosters wider collaboration and increased citations

- maximum visibility for your research: over $100 \mathrm{M}$ website views per year

At BMC, research is always in progress.

Learn more biomedcentral.com/submissions 